University of Pennsylvania Carey Law School

Penn Law: Legal Scholarship Repository

Faculty Scholarship at Penn Law

1992

\title{
The Nature and Effect of Corporate Voting in Chapter 11 Reorganization Cases
}

David A. Skeel Jr.

University of Pennsylvania Carey Law School

Follow this and additional works at: https://scholarship.law.upenn.edu/faculty_scholarship

Part of the Bankruptcy Law Commons, Business Administration, Management, and Operations Commons, Corporate Finance Commons, Economic Policy Commons, and the Finance Commons

\section{Repository Citation}

Skeel, David A. Jr., "The Nature and Effect of Corporate Voting in Chapter 11 Reorganization Cases" (1992). Faculty Scholarship at Penn Law. 1385.

https://scholarship.law.upenn.edu/faculty_scholarship/1385

This Article is brought to you for free and open access by Penn Law: Legal Scholarship Repository. It has been accepted for inclusion in Faculty Scholarship at Penn Law by an authorized administrator of Penn Law: Legal Scholarship Repository. For more information, please contact PennlawIR@law.upenn.edu. 


\title{
THE NATURE AND EFFECT OF CORPORATE VOTING IN CHAPTER 11 REORGANIZATYON CASES
}

\author{
David Arthur Skeel, Jf: *
}

\section{INTRODUCTION}

B ANKRUPTCY theory became something of a cottage industry in the 1980s. Even before the economic slump that marked our transition to the current decade quickly converted hordes of real estate and merger and acquisition attorneys into bankruptcy attorneys, it seemed that every legal scholar with interests remotely related to bankruptcy had something to say about the relatively recently enacted Bankruptcy Reform Act of 1978.' Almost without exception, that commentary focuses upon the role of bargaining in a chapter 11 reorganization. Although bankruptcy scholars disagree as to the appropriate role of bankruptcy bargaining, ${ }^{2}$ they take as a given that

* Assistant Professor of Law, Temple University. I am grateful to Alice Abreu, George Cohen, Saul Levmore, Laura Little, Lynn LoPucki, Ed Rock, Bob Scott, and Bill Woodward for helpful comments on earlier drafts. Financial support for this research was provided by the Temple University School of Law.

1 Pub. L. No. 95-598, 92 Stat. 2549 (codified as amended at 11 U.S.C. $\$ \$ 101-1330$ (1988)). My principal concern throughout the Article is with the reorganization provisions set forth in chapter 11 of the Bankruptcy Code, 11 U.S.C. $\$ \$ 1101-1174$ (1988), and in particular with corporate reorganizations involving large, publiciy held firms. Hereinafter, Bankruptcy Code provisions will be cited as: "Bankruptcy Code \$-."

2 Thomas Jackson proposed a "creditors' bargain" model of bankruptcy in the early 1980s, and he and Douglas Baird elaborated upon the model thereafter. Baird and Jackson argue that the purpose of bankruptcy is to provide a collective proceeding for resolving without alteration the parties' diverse entitlements. See, e.g., Douglas G. Baird, The Uneasy Case for Corporate Reorganizations, 15 J. Legal Stud. 127 (1986): Thomas H. Jackson, The Logic and Limits of Bankruptey Law (1986); Thomas H. Jackson, Avoiding Powers in Bankruptcy, 36 Stan. L. Rev. 725 (1984); Thomas H. Jackson, Bankruptcy, Non-Bankruptcy Entitlements, and the Creditors' Bargain, 91 Yale. L.J. 857 (1982) [hereinafter Jackson, Creditors' Bargain]. Other law-and-economics scholars have suggested refinements to various aspects of Baird and Jackson's analysis. See, e.g., Mark J. Roe, Commentary on "On the Nature of Bankruptcy": Bankruptcy, Priority, and Economics, 75 Va. L. Rev. 219 (1989); Robert E. Scott, Through Bankruptey with the Creditors' Bargain Heuristic, 53 U, Chi. L. Rev. 690 (1986) (proposing a "common disaster" model as a means of explaining the persistent impulse toward redistribution in the Bankruptcy Code).

Another group of commentators rejects the assumptions underlying the creditors' bargain model anc argues instead that the model is overly simplistic and gives short shrift to values crucial to the bankruptcy process. See, e.g., James W. Bowers, Groping and Coping in the 
negotiations among the debtor, its creditors and its shareholders are the crux of chapter $11 .^{3}$

Yet bargaining is only a part of the reorgenization process; chapter 11 points toward, and culminates in, a vote among the various constituencies of the debtor. A complete understanding of the chapter 11 reorganization process requixes an eveluation of hts voting provisions as nuch as of the role of bargaining.

A logical furt place to look for help in understarding the chapter 11 voting rules ${ }^{4}$ is to the voting regime that is displaced when a firm fles its bankruptcy petition. On first inspection, the two sets of voting rules appear quite different. Dutside of bankruptey, corporate voting is governed by state corporation law. In general, these statutes provide that only common shareholders vote, on a ore-vote-per-share basis, ${ }^{5}$ but corporations are free to alter this off-the-rack rule should they so choose. ${ }^{6}$ Although shareholders' principal voting responsibility is to elect the directors who will oversee the activities of the firm, shareholders also vote on the uitimate issues facing a firm. For example, shareholder approval is required for chatter amendments and for fundamental corporate changes such as mergers, sales of most or all of a firm's assets, or dissolution. ${ }^{\text {? }}$

After a chapter 11 petition has been filed, corporate voting is governed by a federally imposed bankruptcy system. Unlike state corporation law, chapter 11 provides only for a single, all-encompassing

Shadow of Murphy's Law: Bankruptcy Theory and the Elementary Economics of Failure, 88 Mich. L. Rev. 2097 (1990); Donald R. Korobkin, Rehabilitating Values: A Jurisprudence of Bankruptcy, 91 Colum. L. Rev. 717 (1991); Elizabeth Warren, Bankruptcy Policy, 54 U. Chi. L. Rev. 775 (1987).

3 See, e.g., Baird, supra note 2, at 145; Raymond T. Nimmer \& Richard B. Feinberg, Chapter 11 Business Governance: Fidueiary Duties, Business Judgment, Trustees and Exclusivity, 6 Bankr. Dev. J. 1, 51 (1989).

+ Bankruptcy Code $\$ \S 1121-1129$; see infra Part II.A. for a detailed description of these rules.

5 See, e.g., Del. Code Ann. tit. 8, § 212(a) (1983).

"A corporation can provide in its charter for cumulative voting, weighted voting, a staggered board, or almost any other designer voting term. Sée, e.g., id. § 102(b) (giving firms significant leeway in tailoring voting provisions to their needs); id. $\$ 214$ (certificate of incorporation may provide for cumulative voting); id. $\$ 221$ (voting rights may be given to bondholders and debenture holders); see also Frank H. Easterbrook \& Dantel R. Fischel, Voting in Corporate Law, 26 J.L. \& Econ. 395, 399 (1983) (overview of corporate voting rules and practices).

7 Del. Code Ann. tit. 8, \$ 242 (1983) (charter amendments); id. $\$ 251$ (miergers): id. $\$ 271$ (sales of most or all of the firm's assets); id. $\$ 275$ (dissolution). 
vote on whether to approve or reject a reorganization plan. A so unlike state corporation law, which limits the franchise to the firm's shareholders, chapter 11 permits every holder of a claim or interest to cast a ballot on the plan, except those who will be compensated in full or who will receive nothing under a given plan of reorganization.

This Article attempts to demonstrate that, despite striking superfcial diferences, chapter 11 voting can and should be seen as an extension of the state corporate law voting rules. Part I proposes a twopronged contractual explanation of sharcholders' monopoly of the franchise outside of bankruptcy. In Part $U$, $T$ apply this explanation to chapter 11 's voting provisions. The analysis demonstrates that chapter 11 's voting rules are responsive to precisely the same nomative concerns that explain shareholder suffrage outside of bankruptcy. I conclude Part II by exploring several positive dimensions of the analogy.

In Part III, I apply my analysis to several particularly troublesome chapter 11 voting issues-including sales of most or all of a firm's assets, directorial elections, and the supermajority requirement for plan approval. The analysis suggests that once in bankruptcy, sales of most or all of a firm's assets should be approved by a majority of the firm's unsecured creditors, rather than by a court. The analysis also suggests that unsecured creditors, rather than shareholders, should be the voters in any directorial election. Finally, Part III argues for replacing chapter 11 's current supermajority yoting standard with simple majority voting to reduce the threat of a creditor's acquiring a blocking position and using this veto power improperly.

In Part IV, I address a potential objection to vesting additional voting power in unsecured creditors. The thrust of this argument is that, because the unsecured creditors of publicly held debtors often are widely dispersed, collective action problems might prevent them from exercising the franchise effectively and thus make it pointless to alter the current voting rules. Drawing on the work of several social scientists, I conduct an in-depth analysis of the parties' collective action dilemma in chapter 11, and of the Bankruptcy Code's (imperfect) solution-chapter 11 committees. The inquiry suggests that

\footnotetext{
\& See Russell Hardin, Collective Action (1982); Mancur Dlson, The Logic of Collective Action: Public Goods and the Theory of Groups (2d ed. 1971); William J. Baumol, Welfare Economics and the Theory of the State (2d ed, 1965).
} 
ursecured creditors would still be, as originally argued, betier voters than judges or shareholders.

\section{IN THE BEGINNING: SHAREHOLDER VOTING OUTSIDE OF BANKRUPTCY}

Nearly a decade ago, Kenneth Scott noted that in the "emerging perspective, the 'entity' of the public corporation is merely a legal device for tying together an interconnecting web of contracts among all the suppliers of factors of production in ways that lover the transaction costs of organizing production." In subsequent years, this nexus-of-contracts perspective has provided important new insights into the nature of publicly held firms. ${ }^{10}$ In this Part, I draw from this and related literature in developing a two-pronged contractual justification for the observation that, outside of bankruptcy, in the vast majority of publicly held corporations the franchise is exercised by a single class of common shareholders under a one-share, one-vote allocation. ${ }^{11}$ My two-pronged analysis brings together the somewhat divergent insights of, among others, Frank Easterbrook, Daniel Fis-

9 Kenneth E. Scott, Corporation Law and the American Law Institute Corporate Governance Project, 35 Stan. L. Rev. 927, 930 (1983). The origins of this perspective date to R.H. Coase, The Nature of the Firm, 4 Economica 386 (1937).

10 E.g., Symposium, Contractual Freedom in Corporate Law, 89 Colum. L. Rev. 1395 (1989) (debating whether corporate law is enabling, as the nexus-of-contracts advocates argue, or mandatory).

11 As noted, corporations enjoy significant freedom to alter this off-the-rack rule. Close corporations in particular often adopt one or more special voting provisions. In the vast majority of publicly held corporations, however, the franchise is exercised by a single class of common stockholders. See, e.g., Easterbrook \& Fischel, supra note 6, at 399-400.

The recent spate of dual class recapitalizations casts an interesting light on this observation. In the face of the takeover wave of the $1980 \mathrm{~s}$, the managers of numerous publicly held corporations sought to insulate themselves by effecting, through exchange offers, a division of their firm's stock into two classes: one class typically would have greater voting rights and be controlled by management; the other class typically would have lesser voting rights but offer larger dividends. Several commentators decried this development and called on the Securities and Exchange Commission ("SEC") to restrict such dual class recapitalizations. See, e.g., Jeffrey N. Gordon, Ties that Bond: Dual Class Common Stock and the Problem of Shareholder Choice, 76 Cal. L. Rev. I (1988) (arguing that firms delisted from the New York Stock Exchange for deviating from the one-share, one-vote norm should be prohibited from listing on another exchange). The SEC's response, Rule 19c-4, 17 C.F.R. \$2 240.19c-4 (1990), effectively banned dual class recapitalizations but subsequently was invalidated. Business Roundtable v. SEC, 905 F.2d 406 (D.C. Cir. 1990). Dual elass recapitalizations are exceptional and thus do not undermine the suggestion that most firms limit voting to a single class of shares in that they occur predominantly in firms with an unusually high percentage of family ownership. See Gordon, supra, at 44-46; Peter N. Floços, Comment, Toward a 
chel, ${ }^{12}$ and Oliver Williamson. ${ }^{13}$ In this Part, I also address shareholders collective action problems and the issue of whether shareholders care about their voting rights. The analysis of this Par: will then be used, in Part II, to examine the voting rules imposed by chapter 11 .

\section{Residual Ownership and the Problem of Agency Cosis}

The itst prong of the contractual analysis of corporate voting is the link between agency costs and the choice of shareholders as keepers of the franchise. ${ }^{14}$ In corporations, agency costs stem from the diver gence of interests between shareholders, who theoretically own the corporation, and the managers, who run the corporation. ${ }^{15}$ More generally, agency costs exist whenever a decisionmaker will not reap the full benefit or bear the full cost of her decisions, and thus lacks the appropriate incentives. Because shareholders have no stake in a corporation's assets until all other claimants have been paid in full, shareholders are the firm's residual owners so long as the firm remains solvent. The significance of this residual ownership status from an agency cost perspective is that it invests shareholders with decision-

Liability Rule Approach to the "One Share, One Vote" Controversy: An Epitaph for the SEC's Rule 19c-4?, 138 U. Pa. L. Rev, 1761 (1990).

12 Easterbrook \& Fischel, supra note 6; Frank H. Easterbrook \& Daniel R. Fischel, The Corporate Contract, 89 Colum. L. Rev. 1416 (1989)

13 See Oliver E. Williamson, Corporate Governance, 93 Yale L.J. 1197 (1984) [hereinatter Williamson, Corporate Governance]; Oliver E. Williamson, Credible Cornmitments: Using Hostages to Support Exchange, 73 Am. Econ. Rev. 519 (1983); Oliver E. Williamson, Transaction-Cost Economics: The Governance of Contractual Relations, 22 J.L. \& Econ. 233 (1979) [hereinafter Williamson, Transaction-Cost Economics].

14 Identifying agency costs is the central insight of the nexus-of-contracts theorists. Seminal contributions to this literature include Eugene F. Fama, Agency Problems and the Theory of the Firm, 88 J. Pol. Econ. 288 (1980); Michael C. Jensen \& William H. Meckling, Theory of the Firm: Managerial Behavior, Agency Costs and Ownership Structure, 3 J. Fin. Econ. 305 (1976); Oliver E. Williamson, Managerial Discretion and Business Behavior, 53 Am. Econ. Rey. 1032 (1963). Easterbrook and Fischel first applied the insights of agency cost analysis to corporate yoting. Easterbrook \& Fischel, supra note 6. In the discussion that follows I draw liberally from their analysis, which has become the standard neoclassical account of corporate voting.

15. Shareholders' delegation of authority to the firm's day-to-day managers is indirect. Shareholders elect ditectors, see, e.g., Del. Code Ann. tit. 8, \$211 (1983), who then hire the officers who oversee the ordinary operations of the firm, see, e.g., id. \$ 142 . 
making incentives superior to those of any other constituency of the firm. ${ }^{16}$

Consider the following illustration comparing shareholders' and creditors' incentives: assume that a corporation's assets currently are worth $\$ 200$, that the corporation owes a bank \$125, that a bondholder, whose clam is subordinated to that of the bank, is owed $\$ 50$, and that the sole shareholder has a claim to the $\$ 25$ residual; assume further that the corporation is presented with an investment opporturity, which, if pursted, carries a $50 \%$ chance the corporation will be worth $\$ 300$ in one year but also a $50 \%$ chance the corporation will be worth oniy $\$ 150$. Clearly, the wealth-maximizing response would be to pursue the opportunity because the present value of the opportunity is $\$ 225$ ( $\$ 25$ more than the current value of the firm). ${ }^{17}$ It is far from obvious, however, that either the bank or the bondholder would encourage the corporation to undertake the venture. The bank is likely to be indifferent to the opportunity because its claim will be paid regardless and it gets no benefit from any upside potential. The bondholder, on the other hand, will actively oppose the venture because the opportunity creates a $50 \%$ chance that she will lose onehalf of her claim whereas she currently expects payment in full. Only the shareholder, whose expected residual interest will increase from $\$ 25$ to $\$ 50$, can be expected to view the venture with enthusiasm. ${ }^{18}$

Shareholders' decisionmaking incentives also are better than those of the managers of the firm, who typically own oniy a small percentage of the firm's stock and thus do not feel the full impact of their

16 See, e.g., Robert C. Clark, Corporate Law \$ 9.5, at 389-90 (1986); Easterbrook \& Fischel, supra note 6 , at 403-06.

17 The value of the opportunity equals the sum of each possible value discounted by the probability of its occurrence. Thus, in the example, the value equals $(\$ 300 \times .50)+(\$ 150 \times$ $.50)=\$ 150+\$ 75=\$ 225$. For the sake of simplicity, 1 have assumed risk neutrality and have ignored the time value of money.

18 To be sure, shareholders' incentives are not perfect. Shareholders may, especially if the firm is in a precarious financial condition, encourage the firm to pursue unduly risky ventures because much of the risk of such ventures would be borne by higher priority creditors, such as the bondholders. Risk-taking of this sort effects a redistribution from creditors to shareholders, for shareholders enjoy much of the upside potential but little of the downside risk. See Easterbrook \& Fischel, supra note 6, at 404; Mark 3. Roe, Bankruptcy and Debt: A New Model for Corporate Reorganization, 83 Colum. L. Rev. 527, 549-53 (1983); infra Part III.A. (detailed discussion of this observation and its implications for corporate voting in the bantruptcy context). Moreover, even appropriate risk-taking by the shareholders may have third-party effects, as is illustrated by the bondholder's potential exposure in the hypothetical. 
decisionmaking. In recent years, some firms have attempted to realign their managers' incentives through a variety of stock option plans and by coordinating even managers base compensation with the perormance of the firm's stock. ${ }^{19}$ The recent controversy concerning the perceived escesses of management compensation provides telling evidence that these measures have not been fully effective ${ }^{20}$

Agency costs also explain in part the tendency to limit voting to on vote per share. If shareholders have a single vote for each share of stock, their yoting power mirrors their economic incentives. By contrast, the creation of disproportionate voting power introduces additional agency costs. Shareholders with more than one vote per share of stock will not receive gains or losses commensurate with the influence they wield and therefore cannot be expected to make optimal decisions on behalf of the corporation. ${ }^{21}$ In sum, because shareholders have decisionmaking incentives superior to managers and all other constituencies, they appropriately hold a monopoly of the franchise outside of the bankruptcy context.

19 See generally Frank H. Easterbrook, Managers' Discretion and Investors' Welfare: Theories and Evidence, 9 Del. J. Corp. L. 540, 559-62 (1984) (arguing that compensation packages such as stock option plans improve managers' decisionmaking incentives); Daniel R. Fischel, The "Race to the Bottom" Revisited: Reffections on Recent Developments in Delaware's Corporation Law, 76 Nw. U.L. Rev. 913, 918-19 (1982) (same).

20 See, e.g., Karen W. Arenson, The Boss: Underworked and Overpaid?, N.Y. Times, Nov. 17, 1991, \& 7 (Book Reviews), at 11 (reviewing Graef S. Crystal, In Search of Excess: The Overcompensation of American Executives (1991)).

2) The problem of disproportionate incentives may also help explain courts' longstanding anipathy toward attempts to buy votes without also buying the shares to which the votes attach. See Macht v. Merchants Mortgage \& Credit Co, 194 A. 19 (Del. Ch. 1937): Easterbrook \& Fischel, supra note 6, at 410-11. But see Schreiber v. Carney, 4.47 A.2d 17 (Del, Ch. 1982) (purchase of voting rights without transfer of stock is not necessarily illegal): Wincorp Realty Invs. v. Goodtab, Inc., No. 7314 (Del. Ch. Oct. 13, 1983) (reported at 8 Del. J. Corp. L. 636 (1983)) (agreement between shareholders involying sale of voting rights is not illegal per se): Thomas J. Andre, Jr., A Preliminary Inquiry into the Utility of Vote Buying in the Market for Corporate Control, 63 S. Cal. L. Rev 533 (1990) (arguing that vote buying provides both bidders and stockholders with an additional financial incentive); Robert $\mathrm{C}$. Clark, Vote Buying and Corporate Law, 29 Case W. Res. L. Rev, 776 (1979) (arguing in favor of permitting "equity-centered" vote buying); Henry G. Manne, Some Theoretica! Aspects of Share Voting: An Essay in Honor of Adolf A. Berle, 64 Colum. L. Rev. 1427 (1964) (concluding that vote selling is invaluable to the functioning of the United States corporate system). See infra note 223 for a more detailed discussion of vote buying. 


\section{Toting Rights as a Generalized Contracual Safeguard}

The second prong of the contractual analysis focuses on the sature of the contractual relationship between shareholders and fims. Many of the contracts into which firms enter are long-term relationships wh supoliers, lenders, and employees. If these ongoing contracts Tequire investment in contract-specific assets or skills, they nay give rise to bilateral monopolies - that is, each of the parties will have a strong incentive to preserve the relationship, rather than to reenter the marketplace at the cost of losing any transaction-specific assat and being forced to redevelop it in a subsequent contract. ${ }^{22}$ The danger in any bilateral monopoly situation is that one party will later behave opportunistically ${ }^{23}$ in an effort to appropriate the monopoly gain. ${ }^{24}$

A similar long-term contractual relationship exists between shareholders and firms, even though shares of stock in publicly held corporations frequently change hands. ${ }^{25}$ Unlike other constituencies, however, shareholders cannot with relative ease safeguard against opportunism by the firm's managers. Employees who have developed (or will develop) firm-specific skills, for example, can contract for severance pay or unionize; ${ }^{26}$ this minimizes the danger that the firm will terminate them prematurely. ${ }^{27}$ Similarly, suppliers who make firmspecific investments can require progress payments or a price pre-

22 Williamson, Corporate Governance, supra note 13, at 1202; Williamson, TransactionCost Economics, supra note 13; see also Robert E. Scott, A Relational Theory of Secured Financing, 86 Colum. L. Rev, 901 (1986) (analyzing the specialized relationship that develops, and is encouraged by article 9 of the Uniform Commercial Code ("UCC"), between a debtor and its principal lender).

23 The terms "opportunism" and "strategic behavior" as used in the text denote inappropriate behavior, that is, behavior that exceeds the bounds of ordinary arms-length bargaining. Williamson defines opportunism as "self-interest seeking with guile." Oliver $\mathrm{E}$. Williamson, The Econotric Institutions of Capitalism 47 (1985).

24 W/lliamson, Corporate Governance, supra note 13, at 1202-05. This problem arises only if transaction-specific assets (such as customized equipment or job-specific employment skills) are at stake. Otherwise, both parties can transfer their assets to another contract at low cost in the event the relationship breaks down. See Charles $J$. Goetz \& Robert E. Scott, Principles of Relational Contracts, 67 Va. L. Rey, 1089, $1100-01$ (1981).

25. Williamson, Corporate Governance, supra note 13 , at 1210 .

26 See Michael I. Wachter \& George M. Cohen, The Law and Economics of Collective Bargaining: An Introduction and Application to the Problems of Subcontracting, Partial Closure, and Relocation, 136 U. Pa. L. Rev. 1349 (1988).

27 The firm itself is similarly protected because employees who quit prematurely may forfeit unvested pension benefits and accrued vacation days. Williamson, Corporate Governance, supra note 13 , at 1208 . 
minm, and bondholders are protected both by a plethora of bond coyenants and by the right to renegotiate their relationship with the firm (or to walk away) at the end of the bond term. Lenders protect themselves not only with provisions defining breach of a covenant or warranty as a default, but also with broadly worded insecurity clauses that authorize the lender to accelerate the debtor's loan if the lender loses fiath in the debtor's ability to service the debt. ${ }^{23}$

Becaise the relationship between shareholders and the firm is not subject to periodic renewal, shareholders do not have the same ability to renegotiate. ${ }^{29}$ In addition, because their investment in a firm can not be traced to any particular assets, shareholders also are unable to create asset-based safeguards. ${ }^{30}$ The shareholders' vulnerability is not absolute. They do have access to a small repertoire of specific safeguards, such as charter provisions and information requirements, but these safeguards provide only limited protection. Unfortunately, it is all too easy for management to amend the corporate charter ${ }^{31}$ or to limit the usefulness of the information that shareholders receive.

The threat of opportunism in this context provides further support for the choice of shareholders as voters. ${ }^{32}$ Because the nature of their relationship with the firm precludes the adoption of a specific, localized governance structure to prevent strategic behavior, shareholders rely on their voting rights and, in particular, on their right to choose

28 The UCC imposes significant restraints on the breadth of creditors' insecurity clauses, however. Most importantly, U.C.C. $\$ 1-208$ permits a creditor to exercise such a clause only if she "in good faith believes that the prospect of payment or performance is impaired." Courts have occasionally applied this "good faith belief in impairment" requirement in other contexts as well. See, e.g., Brown v. Avemco Inv. Corp., 603 F.2d 1367, 1375-80 (9th Cir 1979) (applying the requirement to a due-on-lease default clause). These limitations support the view that creditors are not fully protected by contract.

29 Williamson, Corporate Governance, supra note 13, at 1210. An individual shareholder can of course sell her shares, but the terms of the rights associated with the shares will not change in the hands of the buyer, who will likewise be unable to negotiate.

$30 \mathrm{Id}$.

31 The firm's managers cannot amend its charter without shareholder approval, but in most contexts collective action problems will preclude effective opposition by shareholders. See infra Part I.C. for a further discussion of shareholders' collective action problems.

32 Although the contractual safeguard analysis developed in this Section complements the agency eost/residual ownership perspective discussed in the previous Section, the two start from somewhat different premises. The contractual safeguard analysis questions an important assumption of the residual ownership version of the agency cost perspective-that the markets in which a corporation contracts are fully competitive-and focuses on parties' efforts to minimize the transaction costs that result from such incomplete competition (as when bilateral monopolies develop) 
drectors who will nonitor the behavior of management on their behalf ${ }^{33}$ This idea 31 iso explains the one-share, one-vote rule. If a shareholder had less than one vote per share of stock, the value of the contractual safeguara would be diminished. It is precisely this concern that lies at the heart of the secent controversy over dual class recapitalizations.

Johr Coffee has recently underscored the intuition that creditors and employes, notwithstanding the apparent effectiveness of their safeguards, also may be exposed to the threat of management opportunism. $^{34}$ Coffee frames his analysis as a reconsideration of the puzzle of firms use of free cash flow. Commentators have long viewed with suspicion managers' tendency to retain or reinvest free cash flow even when it seems inefficient to do so. Managerialists and transaction cost economists both have attempted to explain such behavior as "empire building" by managers. ${ }^{35}$ Coffee suggests that an alternative explanation is equally plausible. Coffee argues that, over and above the firm's explicit contracts with creditors and employees, managers implicitly may have promised to protect these stakeholders' interests by retaining cash flow rather than distributing it to shareholders as dividends. The advent of "bust up" takeovers destabilized the implicit bargains, however. Faced with the threat of a takeover, managers often arranged their own leveraged buyouts, thus diverting the firm's cash flow to its former shareholders and perhaps breaching the managers' unwritten contract with the firm's creditors and employees. ${ }^{36}$

33 Williamson, Corporate Governance, supra note 13 , at 1210-11. Therefore, eliminating shareholders' voting rights likely increases the firm's cost of capital. The firm might minimize this effect by giving its shareholders the option of converting their stock into debt.

34 See John C. Coffee. Jr., Unstabie Coalitions: Corporate Governance as a Muiti-Player Game, 78 Geo. L.J. 1495 (1990). Coffee's focus is on the existence and limitations of implicit contracting in the corporate context. The explicit bargains struck by creditors and employees also may afford inadequate protection against strategic behavior, as when the firm uses bankruptcy as a means of evading its contractual obiigations. See, e.g., Joel Kurtzman, Business Diary: Those Irksome Gas Contracts, N.Y. Times, Aug. 4, 1991, § 3, at 2 (Columbia Gas System files for chapter 11 relief to force renegotiation of long-term natural gas contracts, which, because of a drop in natural gas prices, required it to pay up to five times the thencurrent market price).

35 Colfee, supra note 34 , at 1500 . For examples of the managerialist approach, see William J. Baumol, Business Behavior, Value and Growth (1959); Merritt B. Fox, Finance and Industrial Performance in a Dynamic Economy (1987); Williamson, supra note 14.

36. The principal problem with implicit contracting in this context is that managers can defect without compensating the parties injured by their defection. Coffee, supra note 34, at 1535. But see Edward B. Rock, Corporate Law Through an Antitrust Lens, 92 Colum. L. 


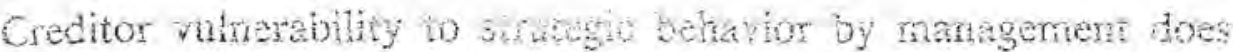
not undermine shareholders clam to the franchise, because shareholders clearly are stil the most sxposed of the firm's constituencies and thes have the greatest reed for woting inghts. Xet Coffee's analysis raises once again a question vigorously debated in the past; shonld sharbolders share their voting rights? That is, should creditors and employees also be entided to vote and to be represented on the board? ${ }^{3 ;}$ One problem from the shichoholders' point of view with expanding the franchise in this faction is that even if shareholders representatives usually controlled board and other voting outcomes, shareholders' contractual safeguards and decisionmaking authority would be undermined by the preserve of constituencies with potentially conflicting interests.

Second, multiple-constitisency representation would affect adversely the decisionmaking apparatus of the corporation as a whole. The ineficiencies created by the presence of multiple decisionmakers are well documented in the literature. Not only would each constituency tend to divert the attention of the board to its own operatinglevel complaints, but when the multiple decisionmakers did consider

Rev. (forthcoming April 1992) (questionsg Colfew's normative assumption that coalitions are desirable).

37 See, e.g., L.C.B. Gower, J.8. Cronin. A.J. Easson \& Lord Wedderburn of Charlton, Gower's Principles of Modern Company Law 9-11 (4th ed. [979); Clyde W. Summers, Codetermination in the United States: A. Projection of Problems and Potentials, $4 \mathrm{~J}$. Comp. Corp, L. \& Sec. Reg. 155, 170 (1982). The argument in favor of extending the franchise arguably derives from the historical debate over whether directors owe duties to all of the constituencies of a firm. See $E$. Merrick Dodd, Irt, For Whom are Corporate Managers Trustees?, 45 Harv, L. Rev. 1145 (1932). The "other constituency" debate has gained new currency in recent years, largely as a response to the takeover wave of the 1980 s. See, e.g., ABA Committee on Corporate Laws, Other Constituencies Statutes: Potential for Confusion, 45 Bus, Law. 2253 (1990) (criticizing states' adoption, as a means of preventing unwanted takeovers, of statutes that permit managers to take other constituencies into account when making decisions on behalf of the firm). Interestingly, employees have shown a much greate: interest than either bondholders or other creditors in protecting themselves through representation on the board of directors. Colitee suggests that employees' greater concern with the identity of the firm's managers results from their having a less viable exit option. Coffee, supra note 34, at 1521. Employees are also particularly vulnerable to the effect of informationsl asymmetries vis-â-vis the fitm and seek representation in part to ensure ongoing access to relevant information. Williamsen, Corporate Governance, supra note 13, at 1208-09. Employees' inability to diversify may also be a factor. 
larger issues, they also would be unlikely to produce a consistent set of management and policy choices. ${ }^{38}$

Finally, the firm would incur significant informational costs in educating the additional constituencies as to the strategies and operations of the irm. In short, expansion of the franchise would generate costs that appzar to outweigh its utility. ${ }^{39}$ A contractual safeguard analysis therefore supports the view that shareholders should retain their monopoly on voting rights.

\section{The Collective Action Dilemma in Corporate Voting}

Having established a double-edged normative justification for shareholders' privileged status with respect to voting, it is time to consider how useful shareholders' voting rights prove in practice. As has frequentiy been noted, significant obstacles hinder effective collective action by the shareholders of a publicly held firm.

The first obstacle is rational apathy. Shareholders, or their agents, must incur significant costs if they wish to cast their vote on any given proposal in an intelligent fashion. These costs include, at the least, the costs of securing relevant information, of developing the capacity to evaluate such information, and of actually evaluating the proposal at hand (or of hiring an agent to perform these tasks). ${ }^{40}$ If the expected payout to a shareholder from informed voting is less than the total of these costs, even a rational shareholder would forgo the benefits of informed voting, because the shareholder will be better off if she simply returns the proxy provided by management and lets management cast her yote.

Free riding discourages collective action even in contexts where the benefits of informed voting outweigh the costs of becoming an informed voter. Widely dispersed shareholders rarely will incur the costs of informing themselves because each knows she will share equally in the benefits of informed voting by her fellow shareholders

38 Kenneth J. Arrow, Social Choice and Individual Values (2d ed. 1963); Easterbrook \& Fischel, supra note 6, at 405; Williamson, Corporate Governance, supra note 13, at 1206.

39 My conclusion that creditors and employees should not enjoy voting rights does not mean to suggest that it would never be appropriate to address managerial opportunism in other ways. See, e.g., Coffee, supra note 34, at 1548 (suggesting that corporate stakeholders should be compensated for the losses suffered as a result of management's breach of implicit contracts in the takeover context).

40 See Manne, supra note 21, at 1440 . 
even if stre does not bother to vote in an informed fashion hersel. ${ }^{41}$ The likelihood of free riding thus creates a classic prisoner's dilemma: it is in shareholders' collective best interest for each shareholder to fully inform herself, but the individually rational strategy for most shareholders is not to do so., ${ }^{42}$ Faced with these barriers, shareholders are more likety simply to sell their shares than to incur the cost.s of becoming an informed yoter and of organizing opposition to management proposals.

Given the dampening effect of collective action problems on meaningful shareholder participation in most contexts, one might question whether shareholders care about their voting rights. Focusing on the constituencies who hold competing (and superior) claims to the assets of the firm suggests a partial explanation for the suspicion that, even in the face of these collective action problems, shareholders would not gladly relinquish the franchise. Simply stated, someone must vote, and what shareholders want is for the votes to be held and cast by parties with interests similar to theirs. ${ }^{43}$ Shareholders may be content to live with the chilling effect of collective action problems on their efforts to organize, no matter how severe, because their retention of the voting right ensures that adverse parties will not possess it.

Another reason shareholders value the franchise is because of its particular importance to the market for corporate control. Takeover bidders typically offer current shareholders a significant premium

4) Free riding comprises a pair of related problems. The first is the impossibility of exclusion: shareholders who inform themselves, and then organize other shareholders either for or against a given proposal, cannot prevent those who do not bother to inform themselves from sharing in the benefits of their efforts. Second, there is no obvious means of compelling all shareholders to contribute to the costs of voting in an informed fashion. See Gordon, supra note 11 , at 44 n.142. The proxy contest reimbursement rules are designed to help overcome these problems by taxing the costs of a proxy fight to the firm, but as a practical matter insurgents are not compensated unless their action both is successful and results in a change in control of the firm. See, e.g., Rosenfeld v. Fairchild Engine \& Airplane Corp., 128 N.E.2d 291 (N.Y. 1955); Clark, supra note 21, at 782.

42 Clark, supra note $16, \S 9.5$, at 391-93. Hardin has demonstrated that the logic of the prisoner's dilemma, which game theorists originally developed in the context of two-person games, applies equally to multiplayer games. Hardin, supra note 8, at 27-28; Russell Hardin. Collective Action as an Agreeable n-Prisoners' Dilemma, 16 Behav. Sci. 472 (1971).

43 I am grateful to Saul Levmore for this insight. The shareholders' concern is both that other constituencies' interests may diverge from their own and also that, if these constituencies do rot face equally debilitating collective action problems, they may be able to act successfully upon those interests. 
over the market price of their shares, ${ }^{44}$ largely because they want to buy the shareholders' voting rights, which are necessary for a successful assertion of control. The desire to be on the receiving end of such a takeover premium further explains why shareholders may care deeply about the franchise, ${ }^{45}$

Finally, recent trends suggest a somewhat different view of the collective uction problem and whether it reduces the large majority of corporate votes to a mere formality. To appreciate these developments, consider first Russell Hardin's analysis of collective action. Borrowing his terminology from Thomas Schelling, Hardin has described the smallest subgroup of a larger group for whom it would be rational to ensure that the larger group provides a collective good ${ }^{46}$ as the smallest efficacious subgroup, or $(k) .{ }^{27}$ Hardin demonstrates that as the ratio of the collective-good benefits to costs increases, the size of this subgroup decreases. ${ }^{48}$ For shareholders, the collective good is informed voting. ${ }^{49}$ Because the benefits to a shareholder of informed voting increase with an increase in the extent of her share-

*4 See Bernará S. Black, Bidder Overpayment in Takeovers, 41 Stan. L. Rev. 597, 601 (1989); Reinier Kraakman, Taking Discounts Seriously: The Implications of "Discounted" Share Prices as an Acquisition Motive, 88 Colum. L. Rev. 891,892 (1988). Commentators dispute the source of the premiums. Compare Frank H. Easterbrook \& Daniel R. Fischel, The Proper Role of a Target's Management in Responding to a Tender Offer, 94 Harv. L. Rev. 1161 (1981) (premiums reflect gains from synergy and improved management) with tynn A. Stout, Are Takeover Premiums Really Premiums? Market Price, Fair Value, and Corporate Law, 99 Yaic L.3. 1235 (1990) (premiums may reflect price pressure rather than efficiency gains).

45 Bankruptcy is another specialized context where shareholders' voting rights may orove important. Shareholders may be able to compel a shareholders' meeting in chapter 11 and to employ this ability strategically. See infra Part III.B. for a more detailed discussion of shareholders' right to compel a shareholders' meeting; see also Lynn M. LoPucki \& William C. Whitford, Shareholders Unite! There's Leverage in Delaware, X ABI News!etter 18, 19 (July 1991) (suggesting that shareholders may wish to cause the firm's chapter 11 petition to be filed in Delaware, rather than New York, due to the greater probability in Delaware that they will be permitted to call a shareholders' meeting).

46 A collective good is one characterized by impossibility of exclusion; that is, if a group supplies such a good, the members who contributed to its provision cannot prevent members who did not from sharing in the benefits of the good. Hardin, supra note 8, at 19.

47 Id. at 41 (citing Thomas C. Schelling, Micromotives and Macrobehavior 213-43 (1978); Thomas C. Schelling, Hockey Helmets, Concealed Weapons, and Daylight Saving: A Study of Binary Choices with Exiernalities, 17 J. Conflict Resol. 381 (1973)).

48 Id. at 40-4 I. See infra Part IV for further discussion of the dynamics of (k). ithe smallest efficacious subgroup, and its significance for groups' efforts to act collectively.

49 Edward Rock's more precise definition of informed voting is "disciplining." Edward B. Rock, The Logic and (Uncertain) Significance of Institutional Shareholder Activism, 79 Geo. 
holdings, the smallest efficacious sibgroup also decreases in size as the concentration of shareholdings increases. Thus, the likelihood that shareholders will overcome the collective action problem depends, at Jeast in part, on the extent to which shareholdings are concentrated in the hands of relatively few investors. ${ }^{50}$

The dramatic increase in institutional ownership of stock has given rise to just such an increase in concentration and has led many commentators to predict substantial inroods on the collective action problem. These commentators are not prophesying in a vachum. Institutional shareholders already have begun to take a more active role in corporate governance, as evidenced by the substantial support that many shareholder proposals-especially those relating to takeovers-have received in recent years. ${ }^{51}$ Though commentators disagree as to whether institutional investors will be effective champions of shareholders' interests, ${ }^{52}$ there seerns to be substantial agreement that institutional shareholder activism is the direction of the future, and thus that the traditional view of shareholders as powerless in the face of the collective action dilemma is no longer fully accurate.

\section{After Disaster: Corporate Voting in Chapter 11 REORGANIZATION CASES}

Sections 1121 to 1129 of the Bankruptcy Code provide an elaborate network of voting rules for the purpose of regulating the chapter 11 franchise. Commentators have considered isolated aspects of the voting rules ${ }^{53}$ and have also addressed various chapter 11 voting issues

L. J, 445, 454 (1991); see also Bernard S. Black, Shareholder Passivity Reexamined, 89 Mich. L. Rev. 520, 522 (1990) (defining the collective good as "shareholder voice").

50 Rock, supra note 49 , at 459 .

5! Id. at 481-84. In fiscal year 1987, 45 shareholder resolutions were approved by more than 20\% of the firm's shareholders. Sharon Marcil \& Peg O'Hara, Voting by Institutional Investors on Corporate Governance Issues in the 1987 Proxy Season app. 55-58 (1987). By 1990, this number had mushroomed to 160. 7 IRRC Corp. Governance Bull., July-Aug. 1990, at $115-23$. In both years the vast majority of resolutions related to takeovers.

52 Compare Rock, supra note 49 (expressing skepticism as to the efficacy of institutional shareholder activism due to agency costs associated with their money managers) with Black. supra note 49 (adopting a more optimistic view).

53 See, e.g., Ethan D. Fogel, Confirmation and the Unimpaired Class of Creditors: Is a "Deemed Acceptance" Deemed an Acceptance?, 58 A.m. Bankr. L.J. 151 (1984) (arguing that a "deemed acceptance" should satisfy the one class acceptance requirement for confirmation of a plan under the original version of Bankruptey Code $\$ 1129(a)(10))$. 
without reference to these provisions. ${ }^{54}$ What they have not done as yet is consider chapter 11 suffrage as a unified whole. In this Part, I bring the insights developed in Part I to bear in an effort to provide such an analysis. My inquiry shows that, despite their major superficial differences, state corporate law voting rules and the chapter 11 voting framework are largely consistent from a nommative perspective. The yoting regime is not perfect, however. I consider several problems with the voting rules and propose possible solutions at the end of the Part. To facilitate both the analysiz of this Part and its application to specific voting issues in Part III, $\mathrm{I}$ defer until Part IV detailed discussion of the parties' collective action problems.

\section{A. An Overview of Corporate Voting in Chapter 11}

Chapter 11 provides a voting framework remarkably different from corporate voting outside of bankruptcy. The crucial distinction lies in section 1126(a), which states that any "holder of a claim or interest allowed under [section] 502 of this title . . may accept or reject a plan." S5 Simply put, whereas shareholders enjoy a monopoly of the franchise before the corporation files its petition, section 1126(a) establishes universal suffrage as the norm in chapter $11,{ }^{56}$ at least to the extent the parties are voting on a reorganization plan.

Understanding the voting regime set forth in sections 1121 to 1129 is central to appreciating the significance of this distinction. Section 1123(a) provides, as a starting point, that the proponent of a reorganization plan must organize the claims against and interests in the corporation into classes. ${ }^{57}$ Section 1126 establishes a system of classified voting on the plan. ${ }^{58}$ Under section $1126(\mathrm{c})$, acceptance by creditors requires the approval of two-thirds in amount and a majority in

54 See, e.g., Raymond T. Nimmer \& Richard B. Feinberg, Chapter 11 Business Governance: Fiduciary Duties, Business Judgment, Trustees and Exclusivity, 6 Bankr, Dev, J, 1, 15-20 (1989) (suggesting that sales of substantial assets prior to confirmation may allow the debtor to subvert the participatory, négotiated process of bankruptcy).

$\$ 5$ Bankruptcy Code $\$ 1126(\mathrm{a})$.

56 Bankruptcy Code $\$ 1126(\mathrm{f})$ - $(\mathrm{g})$ carve out limited exceptions to this norm. See infra note 63 and accompanying text.

57 Id. \$ 1123(a) (requiring a plan proponent to designate classes of claims and interests and to specify any that are not impaired).

55. Id. $\$ 1126$. 
number of the claims in each class of creditors. ${ }^{59}$ Acceptance by a class of interests requires that two-thirds in amount of the allowed interests cast their yotes in favor of the plan. Thus, the emphasis of section 1126 rests on whether the class as a whole votes for or against the plan.

Obviously, in determining which claims or interests belong in a particular class, the plan proponent has a tremendous incentive to choose her classes in such a way as to "rig" the vote if she can. For example, she might place dissident claimants in a class whose other claimants can be courted upon to support the plan and carry the class. Section 1122 (a) imposes significant limitations on this sort of maneuvering, however, by permitting the proponent to "place a claim or an interest in a particular class only if such claim or interest is substantially similar to the other claims or interests of such class."

After the court approves the contents of the plan, including its classification of claims and interests, and every interested party receives an appropriate disclosure statement, ${ }^{61}$ the plan proponent must secure

59 Id. \$1126(c). The "amount" of each creditor's claim is determined in accordance with $\S 502$ of the Bankruptcy Code. Id. $\$ 1126(\mathrm{a})$. Among other things, $\$ 502(\mathrm{a})$ requires the bankruptcy court to estimate the amount of a contingent or unliquidated claim, and $\$ 502$ (b)(5) disallows any claim to the extent it is based on interest that is unmatured as of the commencement of the chapter 11 case. Interestingly, bonds and other debt instruments are allowed in their face amount, even if the debt is trading well below face value at the time of bankruptcy. In re Lorraine Castle Apartments Bldg. Corp., 149 F.2d 55 (7th Cir.), cert. denied, 326 U.S. 728 (1945); Chaim J. Fortgang \& Lawrence P. King, The 1978 Bankruptcy Code: Some Wrong Policy Decisions, 56 N.Y.U. L. Rev. 1148, 1161 n.57 (1981). On the other hand, the unaccrued portion of original issue discount instruments is disallowed as unmatured interest. In re Chateaugay Corp., 109 B.R. 51, $54-57$ (Bankr. S.D.N.Y. 1990), aff'd, 130 B.R. 403 (S.D.N.Y. 1991); In re Allegheny Int'l, Inc., 100 B.R. 247, 250-52 (Bankr. W.D. Pa. 1989).

${ }^{60}$ Bankruptcy Code $\$ 1122$ (a). The precise parameters of this requirement are uncertain. For example, courts have refused to permit a plan proponent to classify trade and institutional creditors separately where the classification was designed to ensure satisfaction of $\S 1129(\mathrm{a})(10)$, which requires acceptance of the plan by at least one impaired class. In re Pine Lake Village Apartment Co., 19 B.R. 819, 828 -31 (Bankr. S.D.N.Y. 1982). Yet they may be separately classified if institutional creditors agree to accept their distribution in the form of debt but trade creditors wish to receive cash. 5 Collier, supra note 59, 1f 1122.04, at 1122-21. See generally Daniel C. Cohn, Subordinated Claims: Their Classification and Voting Under Chapter 11 of the Bankruptey Code, 56 Am. Bankr. L.J. 293 (1982) (discussing the enforcement of subordination by classification and assignment).

61 See Bankruptcy Code $\$ 1125$. Section 1125 requires that the disclosure statement contain "adequate information," defined as information sufficient to "enable a hypothetical reasonable investor ... to make an informed judgment about the plan." Id. The intent is to provide investors with information analogous to that required under the securities laws, while at the 
the afirmative votes of each class of claims or interests to confirm a consensual reorganization plan. ${ }^{62}$ Section $1126(1)$ provides, however, that a class that is not "impaired" under the plan is conclusively presumed to have accepted the plan ${ }^{63}$ and thus the plan proponent need not solicit acceptances from such a class. The language of section 1126 is indirect and its legislative history unclear, but its apparent denial to members of unimpaired classes of the right to vote ${ }^{3+}$ constitutes a significant exception to the universality of the chapter 11 franchise.

For a class to be unimpaired, its treatment under the plan must meet one of three requirements. The plan must: (1) fully preserve the legal, equitable, and contractual rights of each claimant; (2) cure any default under and reinstate the terms of each claim; or (3) pay the allowed amount of each claim in full, in cash, on the effective date of the plan. ${ }^{65}$ Section 1126(f), the "deemed acceptance" provision, reflects the drafters' conclusion that a class that meets any of these requirements has no grounds for complaint and thus no need to vote. ${ }^{65}$

same time ensuring that the requirement not be excessively onerous for the plan proponent. Report of the Committee on the Judiciary, H.R. Rep. No. 595, 95th Cong., 1st Sess. 226-31 (1977), repitinted in 1978 U.S.C.C.A.N. 5963 [hereinafter House Report].

$n z$ If one or more of the classes of claimants or interest hoiders of the firm relects the plan, the pian may still be confirmed under the crandown provisions of Banktuptey Code $\$ 1129(b)$. The most importunt requirement of $\& 1$ I29(b) is the absolute priority rule, which prohibits a class of claims or interests from participating in the plan tunless all higher prioriry claimants have been peid in full. See Bankruptcy Code \& 1129(b)(2): David A. 5ked, The Uncertain State of an Unstated Rule: Bankruptey's Contribution Rule Doctrine After Ahlers, 63 Am. Bankr. L.J. 221, 222 (1989).

63 Conversely, under Bankruptcy Code $\$ 1126(\mathrm{~g})$, a class that would roceive nothing under a plan is presumed to have rejected the plan,

at Fogei. supia note 53, at 154-55. Section $7-309$ of the bill proposed by the Bankruptcy Comnission stated explicitly that creditors not "materially and adversely affected" by a plan would not be entitled to vote, Report of the Commission or the Bankruptcy Laws of the United States, pt. 11, H.R. Doc. No. 137, 93d Cong., 1st Sess. 250 (1973).

of Bankrupicy Code 8 1124.

56 That satisfaction of any one of the requirements will teave a class unimpaired does not mean that the requirements are interchangeable. Reinstating the ternins of a bond that is currently rading well below face value, for instance, woult be significantly less costly to the debtor than repaying the bondholder in full as of the efrective date of the plasi. Rather than paying its full value, in cash, the debtor could repurchase the reinstated bond at its discounted markel value immediately after bankruptcy. See Roe, supra rote 18, at 545-47. 


\section{B. A Normative Assessment of the (Nearly) Universal} Suffrage of Chapter 11

This Section looks at the chapter 11 voting rules described above through the lens of the contractua! analysis developed in part I. This retum to the earlier framework addresses the question whether the chapter 11 franchise is responsive to the same rormative concerns as shareholder voting outside of bankruptcy, or whether chapter 11 yoting is of an entirely different character.

\section{Applying the Residual Ownership Prong to Chapter 11 Suffrage}

At first blush, the chapter 11 voting regime seems wholly inconsistent with the residual ownership perspective on corporate voting. Recall that this view of corporate voting justifies shareholders' exclusive right to vote as necessary to vest decisionmaking power in the firm's optimal decisionmakers, its residual owners. In affording every constituency access to the voting process, chapter 11 abandons the goal of limiting sufirage to the single constituency with the best decisionmaking incentives. The true residual owners vote, but so do numerous classes whose decisionmaking incentives are less desirable.

The analysis is not so simple as this characterization suggests. Consider first the fact that because chapter 11 not only effects a sale of the firm's assets, either to its current claimants and interest holders or to a third party, ${ }^{67}$ but also compromises the claims of most or all classes of claimants, multiple constituency voting is inevitable. Were the vote concerned solely with an issue of general applicability--such as whether to consummate a sale of the firm's assets-a single class of claimants could make the decision on behalf of all of the firm's constituencies. But realistically the drafters of the Code could not have meant to give a single class of claims the authority to determine whether and how to compromise the claims of another class. A rule permitting one class of creditors to alter the claims of another class

67 Robert Clark first pointed out that the reorganization (and scaling down) of the debts of a firm is, in effect, a "sale" of the firm to its current creditors. Robert C. Clark, The Interdisciplinary Study of Legal Evolution, 90 Yale L.j. 1238, 1250-54 (1981). Although critics of the law-and-econonics school believe this analogy ignores the multiplicity of values at stake in chapter 11, see, e.g., Korobkin, supra note 2, at 749-55, 759-61, the metaphor is a useful tool for developing a fuil understanding of the complexity of chapter 11 . 
would create a huge risk of opportunistic behavior by the decisionmaking class. ${ }^{68}$

More important, despite the inevitability of multiple constituency voting, the Bankruptcy Code still seems to focus voting authority on the residual class. The residual class is the first class that will be impaired if the plan proponent seeks to compensate as many classes in full as the firm's assets will allow. Because unimpaired classes of claims or interests are deemed to accept a reorganization plan, full compensation eliminates the ability of a class to vote against the plan. Therefore, the residual class will vote in nearly every chapter 11 case (unless the reorganization plan proposes to pay the residual owners in full but impairs a higher class), and its vote frequently will prove pivotal.

Admittedly, the use of deemed acceptances substitutes imperfectly for a precise determination of the true residual owner. In practice, for instance, reorganization plans often reflect negotiated compromises that impair all but the most senior creditors, and thus numerous constituencies vote. That various classes participate is not inconsistent with the suggestion that the vote of the residual class is crucial, however, for the residual class is the highest priority class whose vote the plan proponent must get, given that the residual class invariably will be impaired. ${ }^{69}$

The following illustration may help clarify the analysis. Suppose that a corporation, with assets of $\$ 1$ million, has filed a chapter 1 ? petition. Claims against the corporation total $\$ 1.3$ million: $\$ 500,000$ owed to the secured creditors, and $\$ 400,000$ each owed to the general unsecured creditors and the subordinated unsecured creditors, with the shareholders entitled to any residual. The corporation, as debtor in possession, proposes a reorganization plan consisting of a sale of

68 Such opportunism probably could be controlled only by strictly limitimg ine decisionmaker's latitude. Chapter 13 of the Bankruptcy Code arguably reflects such a regine.

${ }^{9}$ An interesting analogy can be drawn between the analysis in the text and the median voter theorem developed by fiarold Hotelling and other public choice theorists. In irs simplest form, the median voter theorem suggests that each of the parties in a two-party representstive democracy will be driven toward the viewpoint of the median voter, somewhat as I have argued that the chapter 11 voting rules tend to focus attention on the residual ownership class. The dynamics of an actual election, like those of a bankruptcy case, are much more complex than the unimodal, symmetric preference assumptions of the original model would suggest. Consequently, subsequent theorists have refined the theorem to begin to account for some of these complexities. See Dennis C. Mueller, Public Choice 11, at 179-95 (1989). 
the corporation to a third party for $\$ 1$ million and distribution of the proceeds as follows: $\$ 500,000$ to the secured creditors, $\$ 250,000$ to the general unsecured creditors, $\$ 150,000$ to the subordinated unsecured creditors, and $\$ 100,000$ to the shareholders.

Because the plan proposes to pay the secured oreditors in full, they are unimpaired and may not yote. The general unsecured creditors may yote, but the corporation can silence their class if necessary by proposing to pay them their full $3400,0000^{70}$ The corporation enjoys no such luxury with respect to the subordinated unsecured creditors because compensating the prior two classes in full would leave only $\$ 100,000$ for the subordinated unsecured creditors. As a result, the corporation cannot pass a consensual plan without the support of subordinated unsecured creditors, ${ }^{71}$ and therefore their vote should play an important role in the plan process.

The shareholders are similarly situated in that the corporation cannot pass a consensual plan without their support. ${ }^{72}$ The possibility of a cramdown tempers the importance of their vote, however. If the shareholders refuse to yote for a plan supported by the corporation's other constituencies, the corporation can threaten to amend its plan to comply with the absolute priority rule ${ }^{73}$ under which, in the event the plan proponent fails to obtain the approval of every class, no class of claims or interests may participate in the reorganization inless all superior classes have been compensated in full. Because the shareholders would receive nothing under such a plan, and because every constituency is likely to be aware of this fact, the shareholders should have less leverage than the subordinated unsecured creditors, the firm's true residual class. ${ }^{74}$

70 This "silencing" process is extremely expensive, and debtors cannot usually afford to pay many classes in full. Nevertheless, something like this does go on-sentor cieditors usually get very near their full claim. Their willingness to accept slightly less than full payment teflects their recognition that failure to compromise may result in cosily delay. The effect of this is, at least in a general way, to focus attention on unsecured creditors.

71 Bankruptcy Code $\$ 1129(\mathrm{a})(8)$ (requiring acceptance by every irnpaired class).

72 Id.

73 Sce id. $\$ 1129$ (b)(2); supra note 62 .

74 This effect is vitiated if the parties do not perceive cramdown as a viable option. See supra note 62; infra Part II.C, 


\section{Applying the Contractual Safeguard Prong to Chapter 11 Suffrage}

The expanded sufrage of chapter 11 also makes sense from a contractnal safeguard perspective. Recall that this view of corporate voting justifes shareholders' exclusive right to vote as compensation for shareholders' peculiar inability contractually to sateguatd their interests. $^{75}$

The distinction between shareholders and other constituencies in this regard breaks down in bankruptcy. Several Bankruptcy Code provisions significantly undermine the efficacy of other constituencies' contractual protections. First, the filing of a chapter 11 petition triggers an automatic stay of all efforts to collect a debt from or otherwise enforce rights against the debtor. ${ }^{76}$ Thus, a secured lender loses (at least temporarily) the right to repossess her collateral in satisfaction of amounts owed. Second, the Bankruptcy Code neutralizes the effect of lenders' default and acceleration clauses. The Code permits the hirm to reinstate the maturity of a loan, notwithstanding any prebankruptcy defaults: ${ }^{77}$ after bankruptcy, the lender has no choice but to continue a contractual relationship it otherwise would have been entitled to terminate. ${ }^{78}$ Finally, bankruptcy provides management with a means of forcing employees to renegotiate and make midstream concessions with respect to the terms of collective bargaining agreements and other contracts. Despite the enactment of sections 1113 and 1114

75 See supra Pari I.B.

76 Bankruptcy Code $\$ 362$.

77 Id. 81124 .

75. See, e.g., Jackson, Creditors' Bargain, supra note 2, at $8.87-92$ (suggesting that the Bunkruptcy Code's nonrecognition of ipso facto elauses undermines creditors' bargained-for entitiements). Could a lender whose loan was reinstated attempt to accelerate immediately after bankruptcy, claiming that she is "insecure"-that she had a gocd faith belief her collateral value had been impaired, as required by U.C.C. \$ $1-20$ ? Courts likely would not permit such an action. 
to curit he perceived abuse of this weapon, ${ }^{\text {ty }}$ the status of such fun tracts remains uncertain in bankruptcy. ${ }^{30}$

Nevertheless, bankruptcy does not completeig negate the efiectiveness of contractual safeguards. Though the autonatic stay and the debtor's right to reinstate weaken the posture of creditors, the Code recognizes the importance of preserving creditors' bargained-for ent tiements. Ferhaps the most signincant manifestation of this policy is the absolute priority rule. ${ }^{8 i}$ In a sense, the absolute priority role substitutes for the parties' bargained-for contractual rights. Secured creditors, for instance, bargained most fully as a class to orotect their interests outside of bankruptcy. ${ }^{82}$ Bankruptey neutralizes many of the contractual safeguards of secured creditors, but, in their stead, the absoluie priority rule ensures that even in chapter 11 secured creditors can insist upon compensation prior to any other class. ${ }^{83}$ Thus, secured creditors stand first in line in chapter 11 (and may veto any reorganization plan that attempts to deviate from this standard), just as they do outside of bankruptcy. Similariy, a serior class of bondholders takes priority over the holders of subordinated bonds, and stockholders still are entitled only to any residual interest.

79 Bankruptcy Code $\$ 1113$ provides that collective bargaining agreenents may not be set aside in bankiptcy unless three conditions exist: (1) the trustee has bargained with the unim in sn attempt to reach a mutual agreement; (2) the union has rejectad the trustee's proposals without good cause; and (3) the "batance of equities" clearly favors rejection of the agreenent. Section 1114 sers up similar restrictions on modifications of employee retirement pinns.

*o See, eg., Anne J. MeClain, Note, Bankruptcy Code Section 1113 and the Simple Rejection of Collective Bargaining Agreements: Labor Loses Again, 80 Gec. L.J. 191 (139i).

The uncertainiy of employees' pension benefits under $\$ 3047$ of the Employee Retirement Income security Act of 1974 (ERISA), 29 U.S.C. 1347 (1988), is ampiy attested to by Pension Benefit Guaranty Corp. v. LTV Corp., $110 \mathrm{~S}$. C. 2668 (1990), in which the United Siates Suprenic: Court held that the Pension Benefit Guaranal Cumporation did nor act aribtrarily sud cupriciously in restoring LTV's pension plans, Meventheless. LIV contintied to argue that it could not be compelled to make payments to the restored plans becaise even with stich payments the plans would probably be unable to satisty ouside debts. See Pension Benent Guaranty Corp. v. LTV Corp, 122 B.R. 863 (S.D.N. Y. 1990) (rejectirg this argument, but agreeing that the Supreme Coun had left it open); see also Kurizmen, supra nota 34 , at 7 Columbia Gas System Inc. files chapter 11 petition to force renegotiation of long-term contracts with its natural gas suppliers).

(6) Eankuptcy Code \$1129(b)(2); see supra note 62 .

82 Taking security significantly reduces a creditor's exposure. Eecause oi the reduced risk, a sezured creditor can charge a relatively lower interest rate. Sec Scotl. suprn note 2, at 694.

83 Secured creditors also can seek relief from the automaise stay to foreclose on their collateral under Bankruptey Code $\$ 362(\mathrm{~d})$, which authorizes relief if the secured creditor"s collateral is not "adequately protected" or if the debtor has no equity in the collaterai and the eoliateral is not necessury to an effective reorganization. 
Byen with the surogate safeguards provided by chapter 11 , however, the frm's creditors are far more exposed than before bankruptcy. The absolute priority rule provides broad protection in theory, especially for secured creditors, but its dictates are easily underminget in practice. For instance, courts and the firm's other constituencies view the erandown provisions of secion $7129(\mathrm{~b})$ as a costly and thus undesirable alternative to consensual reorganization because cramdown requires a complete valuation of the firm's assets, ${ }^{54}$ Moreover, in those cases involving a cramdown, the court must make not only an initial valuation of the secured creditor's collateral, but perhaps also a determination of whether a proposed plan will yield her the "indubitable equivalent" of her secured interest, as required by the absolute priority rule. ${ }^{85}$ It is widely believed that secured creditors tend not to get the benefit of their bargain on either occasion. ${ }^{86}$ Finally, unless a creditor is oversecured, its claim ceases accruing interest after the filing of the chapter 11 petition. ${ }^{87}$ Undersecured creditors therefore receive no compensation for the delay in enforcing their contractual rights. The Bankruptcy Code safeguards protecting employees are, as noted above, equally provisional and limited in scope.

Thus, the overall effect of chapter 11 is to undermine creditors' contractual safeguards considerably. The Bankruptcy Code ultimately retums, in the form of surrogate protections, much less than it takes away. As a result, the imbalance between shareholders' need for generalized contractual safeguards such as voting rights, and that of employees and other creditors, is significantly reduced in bankruptcy. Because shareholders no longer have a superior normative claim to the franchise, the contractual safeguard approach implies that each

134 See Lym MI. LoPucki \& Wiliam C. Whitford, Bargaining Over Equity's Share in the Bankruptcy Reorganization of Large, Publicly Held Companies, 139 U. Pa. L. Rev. 125, 143 58 (1990). Lopucki and Whitford conclude that several other factors, including fear of delay and (most importantly) the "intermediated" nature of chapter 11 , also contribute to the parties negative view of crandown. Id.

85 Bankruptcy Code $\$ 1129($ b)(2)(A)(iii).

to See, e.g., Jackson, Creditors' Bargain, supra note 2, at 872-77.

87 Bankrupicy Code $\$ 506(b)$. The Supreme Court has rebuffed creditors efiorts to circumvent this rule by seeking payment of lost opportunity costs under Bankruptcy Code $\$ 362(d)(1)$, which deals with "adequate protection" of a claim. United Sav. Ass'n w. Tiribers of inwood Forest Assoc, 484 U.S. 365 (1988). 
constituency should be, as it is, entrited to vote if its members are impaired by the reorganization plan in question.

The preceding analysis suggests that chapter 11 decisionmaking paralles in important respects the corporate voting rules applicable outstide of bankuptcy. The voting process focuses authority on the firm's residugl oxmer, yet the expanded franchise is consistent with the parties' need for contractual safeguards. Nonetheless, negotiations among the constituencies in chapter 11 often seem to produce voting results that no single class would have chosen. The following Sections will examine one of the causes of this problem.

\section{Shareholders' Role in the Chapter 11 Voting Process}

Although chapter 11's voting rules focus attention on the residual class, the rules cannot completely eliminate the multiple peak prob$1 \mathrm{em}^{88}$ that arises whenever parties with divergent and often conflicting interests make decisions. ${ }^{89}$ The presence of the shareholder constituency in particular most distorts decisionmaking in chapter 11. As the illustration above suggests, shareholders usually have lost their residual owner status by the time a corporation enters chapter 11.90 Because chapter 11 debtors typically are insolvent (though the Bankruptcy Code requires no proof of this), the new residual owners of a publicly held firm are likely instead to be its unsecured creditors, or, as in the illustration, a subclass thereof. ${ }^{91}$

In contrast to the shareholders of a flourishing business, whose incentives further the firm's wealth-maximization goal, shareholders of an insolvent corporation pursue a separate agenda because they

ss See supra note 38 and accompanying text.

89 See Thomas F. Jeckson \& Robert E. Scott, On the Nature of Bankruptcy: Ari Essay on Gankruptcy Sharing and the Creditors' Bargain, 75 Va. L. Rev, 155, 160 (1989) ("the linw cannot ensure that the interests of any particular group of claimants will coincide with this interest of the whole"); Roe, supra note 18, at 538-40 (arguing that the parties' negotiations are subject to significant hold-up risks, due to the numerous parties involved, and that, simply to reach agreemem, the parties often agree to more debt than is appropriate for the lirm's capital structure).

90 See, eg., Topucki \& Whitford, supra note 84, at 141-43. LoPucki and Whitord conducted an extensive empirical study with respect to 43 firms that filed chapter 11 petitions after October 1, 1979 - each declaring assets in excess of $\$ 100$ million. Of the 43 firms. LoPucki and Whittord concluded that 30 were insolvent (at least as of the confirmation date).

91 For closely held firms, this often may not be the case. The principal creditor of a small corporation frequently is a secured lender who holds a security interest in all of the firm's assets. If such a lender is undersecured, it can be seen as the true residual owner. 
with receive nothing upon an inmediate liquidation. First, shareholdAs tray wish to prolong the chapter 11 case as long as possible in the hope that the firrn's fortunes will improve. ${ }^{97}$ Second, they will encoutage gambling with the assets of the firm because they have voling ro lose, and everything to gan, if the frm takes extraordinary wasiness risks. ${ }^{93}$

Given shareholders' questionable incentives, one could argue that shareholders' role in the decisionmaking process should be constrained or even eliminated once a firm enters chapter 11. Yet the chapter 11 voting framework has precisely the opposite effect in practice, given the rarity with which cramdown provisions are invoked. Because the emphasis in most chapter 11 cases is on consensual reorgurization, the plan proponent must secure shareholders' support, notwithstanding shareholders ${ }^{*}$ lack of entitlement to any distribution in a cramdown situation. Shareholders obwiously will, and do, exact a price for their yoting support.

The question that emerges is whether chapter 11 should eliminate shareholders' yoting rights if the firm is insolvent. ${ }^{94}$ Withholding the franchise from shareholders would further focus decisionmaking authority on the true residual class. Moreover, limiting shareholders' tight to vote in this fashion is not unfair to shareholders because arguably they have no financial interest in an insolvent firm.

At least two arguments can be made in support of the current voting regime, however. First, were an insolvent firm liquidated today,

Jackson \& Scott, supra note 89, at 158-59 (noting that lower classes want the debtor to continue in business because they expect to fare poorly in a liquidation).

${ }^{3} 3$ id. The bankruptcy of Arlan's Department Stores ("Arlan"s") offers a vivid example of this phenomenon. After Arlan's filed for bankruptey relief in 1970, its managers engaged in a iast-ditch efiort to reverse the store's fortunes. They spent a significant portion of its funds hirigg (without court approval) a special consultant, who directed an elaborate campaign that irfolved altering the layout of the stores, stocking new and different mercinandise, and conducting a costiy promotional campaign. This step was designed to maximize Arlan's profits during the 1973 Christmas shopping season. Sadly, the campaign failed, and Arlan's sybsequentily was liquidated. See in re Arlan's Department Stores, 462 F. Supp. 1255, 1259 (5.D.N.Y. 1978), aff'd, 615 F.2d 925 (2d Cir. 1979).

it Both Nark Roe and Lucian Bebctuk, etch of whom has offered a dramatically new model for chapter 11 reorganization, have designed new systems that tend toward strict adaerence to the absolute priority rule and thus would have s similar effect. See Lucian A. Bebchuk, A New Approach to Corporate Reorganization, 101 Farv. L. Rev. 775 (1988) (proposing that claimants and interest holders be given tradable options in the reorganized entity); Roe, supra note 18 (proposing an all-equity capitalization. the value of the equity to be determined by offering $10 \%$ for sale on the markct). 


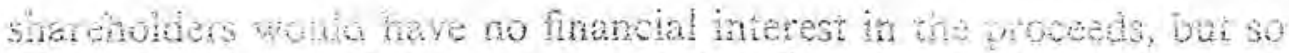
long as the firn contintes to operate there is a chance that its fortunes will improve dratratscaly and again give value to the shareholders" ownersbip interest. This possibility of future value disoounted to the

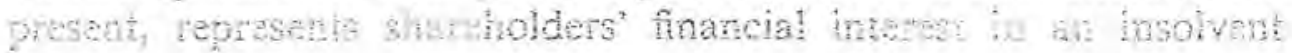
Wint.

Second, pemutug shareholders to participate in the ohapter $t$ process may be necessary to create the proper incentives to enter bankruptoy. if sharholders were entirely exchded fon the process, nanagers of an insolvent firm might prefer to delay going into bankruptcy rather than risk sacrificing shareholders interests to the good of the frm as a whole. Notice that neither of these arguments denies that shareholders' incentives are suboptima! and that their presence thus tends to skew the decisionmalsing process. Father, each argument suggests that shareholders should retain their voting rights despite this fact.

Lym LoPucki and William Whitord have suggesed a possible compromise position. They argue that courts could fud in an appropriate case that the shareholders have no plausible entitlement to participate in any distribution and therefore are not a party in interest. ${ }^{95}$ Their rule would eliminate shareholder sufirage with respect only to a chapter 11 debtor whose debts far exceed its assets. ${ }^{97}$

It is beyond the scope of this Article to assess fully the various positions on this thomy issue. The important point for present purposes is that becanse chapter 11 permits shareholders to vote even in conerts where their incentives are skewed, and because the parties seldom resort to cramdown, shareholder sufirage of en undermines the enciency of the chapter 11 franchise.

${ }^{12}$ Se Alan Schwartz \& Robert E. Scott, Commercial Trensaetions: Principles and Policies 887 (2d ed. 1991).

th 1,opucki Whitord supra rote 34 , at 186.

$n$ id. One question that migh arise with respect to the Lopueki and whitford piogusal is whether cours ever would invoke it. One suspects that courts would be exeedingly willing to find some hope of an equity recovery, especially if the determination were sade early in the casse- 


\section{The Majorty in Number/Two-Thirds th Amount Woing Reguirement}

As discussed earlier, the one-share, one-vote requirement for ditareholder voting outside of bankuptcy is explained by the direst colatonship between the rumber of shares owned and the fmancial stake in the firm. Accounting for creditors' interests proves more difficult, for their claims differ vastly in origin and amount. As a result, chapter 11 requires not only that a majority in number of the claims in a class approve a reorganization plan, but also that two-thirds of the total anount vote in favor. The voting standard thus includes aspects both of a majority and of a supermajority standard. ${ }^{98}$

In practice, the two-thirds in amount prong is the more significant hurdle because a plan proponent who secures the affirmative votes of two-thirds in amount of the claims in a class usually also will have secured well over a majority in number, ${ }^{99}$ Section $1126(\mathrm{c})$ has, therefore, the effect of a simple supermajority requirement. Section 1126(d) makes this explicit with respect to shareholders by requiring as a prerequisite to acceptance that two-thirds in amount of a class of interests cast their votes in favor of a plan.

Why then was a supermajority standard adopted for the purposes of shapter 11 voting? The legislative history sheds little light on this question, even though the two-thirds acceptance requirement deviates both from the old chapter XI voting standard and from the recom-

98 The voting requirement of Bankruptcy Code $\$ 1126(c)$ derives in part ftom o!d Chapter $X$ and in part from old Chapter XI. Section 179 of Chapter $X$ based accentance on the affirmative vote of two-thirds in amount of the claims in a class. 11 U.S.C. $\$ 579$ (repealed). Section 362(1) of Chapter XI, on the other hand, required acceptance by a majority in amount and a majority in number. 11 U.S.C. \$762(1) (repealed). Bankrupicy Code $\$ 1126$ deviates from its antecedents in that, whereas old $\$ \$ 179$ and 362 required the appropriate majorities of all claims in a class, regardless of whether the claimants voted, \$ 1126 requires only a majority in number and two-thirds in amount of the claims actually voted. Thus, failure to yote is no longer equivalent to tejection. See 5 Collier, supra note 59, I 1126.03, at $1126-11$ is -12 .

99 This generalization may not hold true if the class contains claims of dispromortionate size, Another possible deviation results from the trading of bankruptcy claims. If en investor purchases large numbers of claims in a particular class, a court might give her only a single vote, rather than one vote for each claim. See Chaim J. Fortgang \& Thomas M. Mayer. Trading Claims and Taking Control of Corporations in Chapter 11, 12 Cardozo L. Rev. 1, 3691 (1990). The effect would be to dilute the claimant's voting power and, in an extreme case. to enhance the importance of the majority-in-number requirement. 
mendations of the 1973 Report of the Commission on the Bankruptcy Laws, each of which provided for simple majority voting. ${ }^{100}$

Two concerns undoubtedly played a role in the drafters' choice. First, reorganization plans effect en alteration of the prebankruptcy contractual rights of dissenting voters against their yishes. Although the constitutionalng of the Bankruptcy Code provisions that bind dissenters to the majority will has long been settled, ${ }^{\text {iol }}$ the drafters may have concluded as a matter of policy that a supermajority vote was needed to justify such an effect.

Second, like shareholders, the creditors of a publicly held corporation may be small and dispersed enough so that they have insufficient incentives to cast their votes in an informed fashion for or against a reorganization proposal. ${ }^{102}$ Because this would give a plan proponent the upper hand, ${ }^{103}$ the drafters may have concluded that the proponent should be required to secure the support of two-thirds of the voters, in effect using the supermajority requirement as a partial response to voters' collective action problems.

Whatever the rationale, the drafters' adoption of a supermajority standard is misguided. Consider how supermajority voting is used in close corporations, the most prevalent context of such arrangements. In contrast to the shareholders of publicly held corporations, shareholders of close corporations are both investors and managers. ${ }^{104}$ Supermajority voting standards protect the minority shareholders of a closely held firm by giving them veto power over business decisions. A minority shareholder's major fear is that the majority shareholders may one day limit or cut off her access to the income generated by the firm. ${ }^{105}$ To protect herself, the minority shareholder of a four-share-

100 On the other hand, the two-thirds voting requirement is consistent with former Chapter X. See supra note 98 .

101 See infra notes $120-2]$ and accompanying text.

102 See infra Part 1V for a discussion of creditors' collective action problems in chapter 11.

103 Moreover, many of the voters in question are likely to be trade creditors, whose rational apathy is intensified by their willingness to accept any payment-however small-rather than face further delay.

104 See, e.g., Del. Code Ann. tit. 8, \$ 351 (1983) (charter of close corporation may contain provision providing that the shareholders rather than directors manage the corporation).

105 As John Hetherington, Níchael Dooley, and others have pointed out, because there is unlikely to be a market for minority interests in a closely held firm, minority shareholders could be trapped in the event the majority turns against them. E.g., J.A.C. Hetherington $\&$ Michael P. Dooley, Mliquidity and Exploitation: A Proposed Statutory Solution to the Remaining Close Corporation Problem, 63 Va. L. Rev. 1, 5-6 (1977) 
holder firm, for example, would desire adoption of an eighty percent voting requirement, for this would ensure that the other three shareholders could never fre her or vote themselves pay raises without giving her a comparable raise.

Minority protection comes at a prick, however a monorly shere. holder may also use her veto power strategically, as a weapon designed to extract concessions from the remaining shareholders. This cost is justified, and supermajority voting is thus decirable, if the actions taken by majority shareholders could have a disproportionate effect on the minority, as in a close corporation. ${ }^{106}$ The franchise operates very differently in chapter 11 , however. The chapter 11 vote determines whether a class accepts or rejects the terms of a particular reorganization plan. If the class votes in favor of a plan, and the plan is confirmed, every member of the class receives exactiy the same distribution. ${ }^{107}$ Similarly, rejection of the plan precludes any member of the class from receiving a distribution until such time as another plan is proposed and confirmed. Because each member of the class is affected in the same way by the outcome of the vote, there is no need to impose supermajority voting as a protective device, ${ }^{108}$ For similar reasons, whereas states traditionally have required the approval of two-thirds of a firm's shareholders to effect fundamental corporate changes such as mergers, the current trend clearly is roward simple majority voting in these contexts. 109

\section{E. Positive Aspects of the Analogy Between Chapter 17 Voting and Voting Under Siate Corporate Law}

This Part began with the observation that sections 1121 to 1129 of the Bankruptcy Code displace state corporate voting provisions with

100 See id.; see aiso Frank H. Easterbrook \& Daniel R. Fischel, Olose Corporations and A.gency Costs, 38 Sian. L. Rev. 271, 296-97 (1986) (arguing that, in deciding whelther a minority shareholder in the close corporation context has violated a fiduciary dity by blocking a decision, courts should consider whether the decision is question was hikely to have had a disproportionate impact).

167 See Bankruptcy Code $\$ 1123(d)(4)$.

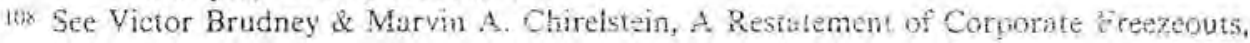
87 yale L.J. 1354, 1357 (1978). This is not to say that class members will never have divergent interests or alterior motives: a trade creditor may have a vested interest in the continued existence of the company, for instance, or other investors uftimately may wish to take the company over. Rather, the poin is that class members cannot use difierental ireatment within the class as a means of acting on such motives.

I(x) See, e.g., Del. Code Ann. tit, 8, \$ 251 (Supp, 1990). 
what appears to be a largely unrelated yoting regime. I suggested thereafter that the apparent divergence is misleading; the chapter 11 franchise is surprisingly consistent with the residual ownership and contractual safezuexd perspectives that justify the shareholderst monosoly of the fanchise outside of bankruptcy. Yht the dramatic swpertial distactions remain. It is helpful at this point to entich futher the comparison between the two schemes. The remainder of this Part demonstrates that, in addition to working on a normative level, the andogy between chapter 11 suffrage and voting outside of bankruptcy is also descriptively plausible.

If state corporate governance rules rather than the Bankruptcy Code governed chapter 11 reorganization, the reorganization would give rise to shareholders' voting rights for each of two reasons. First, chapter 11 effects a sale of all or substantially all of the firm's assets, aither to a third party (if there is an explicit sale) or to the firm's current creditors through the reorganization process. ${ }^{110}$ Second, chapter 11 leads to a substantially altered corporate charter: for instance, it requires the inclusion in a reorganized firm's charter of a provision prohibiting the issuance of nonvoting stock ${ }^{111}$ and also permits the firm (with the appropriate vote) to alter the rights of its current interest holders and to issue new stock. ${ }^{112}$

Although this recharacterization of chapter 11 helps explain the existence of voting rights, we still need to explain from a positive perspective why only one class of shareholders votes outside of bankruptcy, whereas the franchise is nearly universal in chapter 11. The missing link between these apparently divergent voting regimes can be found in the special class voting rules applicable outside of bankAptcy. Most state corporation statutes require that the holders of outstanding shares of a class be permitted to vote on any amendment that alters the nature of their stock, even if the afrected shareholders would not otherwise be entitled to vote. ${ }^{13}$ To pass, such an amendment must be favored by a majority of all stockholders entitled to vote

\footnotetext{
110 See Clark, supra note 67.

14 Dankruptcy Code \$ $: 123(a)(6)$.

112 Sce id $\$ 1123(a)(5)(H)$ (authorizing the "exlension of a maturity date or a change in an interest rate or oiher term of outstanding securities"); id. \$ 1123(i)(5)(1) (contemplating amenciment of the firm's charter).
}

1ti zee Del. Code Ann. tit. 8, \& 242(b)(2) (1983). 
and also by a majority of those in the affected class. ${ }^{11 *}$ Thus, even without the Bankruptcy Code, common shareholders" usual monopoly on suffrage would give way to a more broadly inclusive regime once chapter 11 events occurred. ${ }^{115}$

The analogy batween state corporate lay woing zules and thate spplicable in chapter 11 also has a historical dimonaton. The the Tats ninetenth century, fundamental changes such as mergers and chater amendments required unanimous shareholder tpprowal "16 This standard protected the interests of minority shareholders, as interded, but also impaired firms' ability to adjust to their markets and to take desirable entrepreneurial risks, because any proposal could be vetoed by a single shareholder. ${ }^{117}$

Subsequent state corporation statutes tried to accommodate both goais. To enhance the firms' fexibility, states replaced che unanimity requirement with majority voting. Minority shareholders were compensated for their loss of protection with appraisal rights. ${ }^{118}$ This remedy allows a shareholder who is dissatisfied with a merger, or other fundamental change in the firm approved by a majority, to demand that the corporation repurchase her shares at a price deter-

\footnotetext{
114 Id. $\$ 242(b)(1)$.
}

115 Although special class voting rules apply specifically to changes involving shares of stock, the analogy easily extends to alterations of creditors' claims. For example, the firm cannot alter the terms of a bond absent approval of the holders who would be affected. Outside of bankruptcy, even supermajority approval often will not suffice to effect such a change. See Mark J. Roe, The Voting Prohibition in Bond Workouts, 97 Yale L.J. 232 (1987) (criticizing \$ 316 of the Trust Indenture Act, which prohibits modification of the core terms of a bond without the bondholders' unanimous consent). As a result, firms sometimes resort to bankruptcy when they wish to alter (that is, scale down) bond terms. See In re The Southland Corp., 124 B.R. 211 (Bankr. N.D. Tex. 1991); George Anders, Miemorex Plans 'Prepackaged' Bankruptcy, Wall St. J., July 17, 1991, at A3 (discussing Memorex's plan to file a chapter 1] petition, together with a prenegotiated reorganization plan, to restructure $\$ 1.3$ billion in debt): Barbara Demick, The Rise of Instant Bankruptcy, Phila, inquirer, Alig, 4, 1991, at D1 (describing the use of "prepackaged" bankruptcies to scale down debts snd quickly energe from chapter 11).

16. Armstrong y. Marathon Oil Co., 513 N.E.2d 776, 782 (Ohio 1987); Eltiott J. Weiss, The Latw of Take Out Mergers: A. Historical Perspective, 56 N.Y.U. Z. Rer. 624, 527 (1981).

117 American Law Institute, Principles of Corporate Governance: Analysis and Recommendations 607-09 (Tent. Draft No, 11, 1991).

148 Weiss, supra note 116, at 624-28. But see Hideki Kunda \& Gaul Lermore, The Appraisal Remedy and the Goals of Corporate Law, 32 UCLA L. Rey. 429, 430 (1985) (questioning the view that the elimination of shareholder unanimity requirements prompted the advent of the appraisal remedy). 
mined in court. ${ }^{19}$ Not surprisingly, minority shareholders rebelled at the substitution of appraisal rights for their former veto power. Disgruncled minority shareholders challenged the state law provisions permitting a corporation to alter the terms of its stock and to effect other amenoments to its charter against the dissenters' wishes as violative of the Contracts Clause in Article I of the Constivtion. These protases poid of in a few of the early cases, ${ }^{120}$ but subsequent com. plaints have proven fruitless. ${ }^{12 i}$

Developments in bankruptcy law have followed a very similar pattern. As with corporations outside of bankruptcy, reorganization efforts in the nineteenth century were hampered by an inability to bind minorities. An amendment to the Bankruptcy Act of 1898 , section $77 \mathrm{~B}$, remedied this problem by establishing a system of majority rule and thus eliminating the need to resort to cumbersome equity receiverships as a means of effecting a corporate reorganization. ${ }^{122}$ The current Bankruptcy Code can be seen as compensating minority claimants for their loss of clout by providing what arguably is a counterpart to corporate law appraisal rights. ${ }^{123}$ Section $1129(\mathrm{a})(7)$ of the

119 See, e.g., Del. Code Ann. tit. 8, § 262 (1983).

120 See, e.g., Keller v. Wilson \& Co., 190 A. 115, 125 (Del. 1936) (Contracts Clause prohibited charter amendment that eliminated accrued and unpaid dividends, despite majority approval, because accrued dividends constituted a vested property right,). Keller was subsequently undercut by Federal United Corp. v. Havender, 11 A.2d 331 (Del. 1940), which held that a corporation could achieve the same effect through a merger. See Hottenstein \% York Ice Niach. Corp., 136 F.2d 944, 950 (3d Cir. 1943).

121 See, e.g., Goldman v. Postal Tel., 52 F. Supp. 763, 769 (D. Del. 1943):

Since the corporation is the creature of the state, and since the corporation law is a part of the corporate charter, it is self-evident the state has the right to reserve to itself, or a majority or more of the stockholders, the power to change the contract between the corporation and its stockholders or between its different classes of stockholders by an amendment to the charter after such contracts are made, even if a particular class of stockholders must suffer slightly.

112 Act of June 7, 1934, ch. 424, 48 Stat. 911, 913-14 (1934); see John Gerdes, Corporate Reorganizations Under Section 778 of the Bankruptcy Act \$ 20, at 64 (1936). Pricr to section $77 \mathrm{~B}$, fims reorganized through a fictional sale in equity receivership. A major oroblem with this process was the necessity of cashing out every minority claimant of shareholder who dissented from the plan. Id. \$17, at 55-56.

123 Section $77 B(b)(5)(c)$ had pravided for appraisal and payment of a class of claims that voted against a proposed reorganization plan but did not make specific provision for dissenting clamants in a class that, as a whole, approved the plan. VIII Securities and Exchange Comm'n, Report on the Study and investigation of the Work, Activities, Personnel and Functions of Irotective and Reorganization Committees 138, $141 \mathrm{n}, 215$ (1940). In theory at least, these claimants were protected by the requirement that every reorganization plan satisfy the dictates ô the absolute priority rule. Id. at 151-52. 
Bankruptcy Code provides that the banknptey court cannor confrm a. reorganization plan uniess the dissenting nembers of a class that votes in favor of the plan will recalve as much or more than the amount they would receive in a liquidation. $2 \%$ Like their corporate law countemats, Gigunder chaments hatinlly resisted hese developments and conandet thet the bunkuntey laws facilated inpairment of their contractust xights. Courts have rejected these arguments and have upheld the barkidutey provistons that bind minorities just as they afirmed analogous sections in state corporation law statutes. 125

\section{AN ANALYSIS OF CHAPTER 11 VOTING ISSUES}

As noted in the hntroduction, courts and commentators tave always characterized chapter 11 solely in terms of the negotiations that take place among the parties. The first two 2 arts of this Article drew out the analogy between chapter 11 voting rules and state law corporate voting rules from both a normative and a positive perspective. We now are ready to apply the analysis of Parts I and II to three controversial chapter 11 issues: sales of most or all of a firm's assets prior to confirmation, the sharenolders' right to compel a sharehold. ers' rreeting, and the acquisition and exercise of a blocking position in a class (or classes) of claims. Understanding these issues as voting

124 Bankruptcy Code $\$ 1129(a)(7)$. Interestingly, both \& $1129(2)(7)$ and corporate las: appraisal rights have been criticized for failing to give dissenters the full going concern vaitue of their clains. Sce Jackson, Creditor' Bargain, supra note 2, at 893 n. 168 (suggesting that the liquijation value provided in $\$ 1 / 29(2)(7)$ should refiect the possibility that liquidation may consist of the sale of the firm intact to a third party); Elmer Schaefer, The Fallicy of Weighting Asset Yalue and Eumings Value in the Appraisai of Corporate Stock, $55 \mathrm{~S}$. Cal. L. Rev. 103i (1982); Weiss, supra note 116, at 680.

Commentators also have cribicized the reguirementy stareholders foust satisfy to invoke their appraisal rights. E.g., Joel Seligman, Reappraising the Appraisal Remedy, 52 Geo. Wash. L. Rev. 82\%, 334-36 (1984), in Delaware, for instance, a sharefolter must deliver a writter demand for syptassai rights to the corporation pror to the vote in question, nust demand a valuation withis 120 days of the corporate change, and cannot vote her stock of receive dividends white the petition is pending. Del. Code Am. 4 it. 8,3262 (c)-(o), (k) (1933) The Delaware Supreme Court recognised and addressed many of these problems with the appraisal remedy in Weinherger $x$. WOP, inc, 457 A.2d 701, 714 (Del. 1983), but was not persuaded that the posotblity of synergy gains should be taken into consideration. See A.merican Law Institute, supra note 117 , at 616 .

125 Camplell y. Alleghany Comp. 75 F.2d 947, 951 (Ath Cir), cert. denied, 296 U.S. 581 (1935): see Gerdes, supra note 122, \$22, at 85.87 . 
issues helps clarify some of the confusion that has plagued judicial and academic analysis of bankruptcy.

\section{A. Sales of Substantial Assets Prim to Confimation}

Section $363(b)(1)$ of the Bankraptey Code whorizes the Dankruptcy trustee, after nowice and a hearing, of sell assets of the firm ontside of the ordinary course of business. ${ }^{26}$ The section clearly contemplates that the trustee may sell minot portions of the debtor's business, such as a particular piece of equintent that the firm would not routinely sell (and might not have sold but for the need to scale down in bankruptcy). What is less clear is whether section 363 (b)(1) also gives the trustee the power to sell all or substantially all of the assets of the firm.

\section{Iudicial Analysis: A Description and a Critique}

Two United States Circuit Cout of Appeals decisions, in re Braniff Airways ${ }^{127}$ and in re Lionel Corp., ${ }^{123}$ have addressed this issue. In Braniff, Braniff Airways, Inc. ("Branif") sought approval of an agreement that not only would have resulted in the sale of Branifir's landing slots to a third party, Pacific Southwest Airlines ("PSA"), but also would have assured shareholders and unsecured creditors a distribution in connection with any subsequent reorganization plan, and that Braniff's secured creditors would cast their votes in favor of the plan. ${ }^{129}$ The United States Court of Appeais for the Fifth Circuit, although recognizing that under certain circumstances a firm may sell most or all of its assets pursuant to section $363(\mathrm{~b})$, struck down this agreenent because it purported to "[dictate] some of the terms of any future reorganization plan." ${ }^{3130}$

\footnotetext{
126 Bankruptcy Code \& 363(b)(1).

127700 F.2d 935 (5th Cir. 1983).

128 722 F.2d 1063 (2d Cir. 1983).
}

124 In particular, under the agreement with PSA, Brantit would have paid $\$ 2.5$ milion for 57.5 million of PSA travel scrip, which it could have issucd only to Brariff shateholders and unsecured creditors. The agreement also required Braniff's secured erediors to vote a stated amoun of their unsecured deficiency clam in fuvor of any reorganization plan supported by the unsecured creditors' committee, and provided for the release of any potential claims against, among others, Braniff and its offecers and directors. Bronifi, 700 F.2d at $939-40$.

130 Id. at 940. According to the court, approving this agteement would have improperly circumvented the chapter 11 prerequistes for confirmation-safeguards such as the disclosure 
In contrast, in Lionel the court addressed directly the sale of most or all assets issue ${ }^{131}$ and concluded that such sales should not be approved unless there is "some articulated business justification, other than appeasement of major creditors, for using, selling or leasing oroperty out of the ordinary course of business. ${ }^{4132}$ "The court held that no such justification had been shown after chatgeteriaing the standard as an attempt to balance the need for Reybilisy in furthering the goals of chapter 11 with the loss of chapter tI's disclosure and voting protections when a court approves a sale of most or all of the firm's assets prior to confirmation under section $363(b){ }^{133}$

Following Braniff and Lionel, courts have recognized that authorizing sales of substantial assets pursuant to section 363 undermines the statutory scheme of chapter 11 and have responded by attempting to devise as a prerequisite to approval their own substitute for chapter 11's protections. Courts typically subject proposals to sell substantial assets to enhanced scrutiny, requiring (as in Lionel) the debtor or other applicant to demonstrate a "good business reason" or an "articulated business justification" for the sale. ${ }^{134}$ Another approach is to require a showing that interested parties have received notice comparable to the disclosure mandated by section 1125 in the context

requirements of $\S 1125$, the voting requirements of $\S 1126$, the best-interests-of-creditors test of $\$ 1129(\mathrm{a})(7)$, and the absolute priority rule of $\$ 1129(\mathrm{~b})$. Id.

13 in Lionel the debtor sought approval of the sale of its most valuable asset, an $82 \%$ interest in Dale Electronics, Inc., to a third-party buyer for $\$ 50$ million. The sale was supported by the Creditors' Committee, which apparently had been a driving force behind it, and opposed by the Equity Holders' Committee. Lionel, 722 F.2d at 1065-66.

132 Id. at 1070 (emphasis added).

131 Id. at 1066 . Under the previous bankruptcy laws, courts had been extremely reluctant to approve preconirmation sales of substantial assets and required as a prerequisite a showing of perishability or other emergency. See, e.g., In re Pedlow, 209 F. 841,842 (2d Cir. 1913) (standard satisfied by sale of handkerchiefs that would lose considerable value uniess sold during Christmas season).

134 For cases approving sales, see, e.g., Stephens Indus. v. McClung, 789 F.2d 386, 390 (6th Cir. 1986); In re Delaware \& Hudson Ky, Co., 124 B.R. 169, 179 (D. Del. 1991); in re Engineering Prods. Co., 121 B.R. 246, 249 (Bankr. E.D. Wis. 1996); In re Thomson MeKinnen Secs., 120 B.R. 301, 309 (Bankr. S.D.N.Y. 1990); In re Charnel One Communications, 117 B.R. 493, 496 (Bankr. E.D. Mo. 1990); In re Ciowthers WoCall Patterr, 114 B.R. 877,890 (Bankr. S.D.N.Y, 1990); In re Oneida Lake Dev, 114 B.R. 352, 356 (Bankr. N.D.N.Y. 1990); In re Naron \& Wagner, 88 B.R. 85.90 (Bankr. D. Md. 1988). But see in re George Walsh Chevrolet, 118 B.R. 99, 102 (Bankr. E.D. Mo. 1990) (denying sale).

Unlike Braniff and Lionel, none of these cases involved a publicly held firm. Courts may be coore willing to approve preconfirmation sales for privately held firms because of a greater likelihood that the firm's assets are completely encumbered. 
of a reprganization plan. ${ }^{135}$ Most commentators seem to applaud this treatment of the issue as both sensible and consistent with chapter 11 25 a whole. For example, Raymond Nimmer and Richard Feinberg che Braniff, Lionel, and their progeny as support for their overail concencion of business governance in chaptor $11{ }^{135}$ According to Winmer and Fenberg, the debtor in pussession snjoyz brod

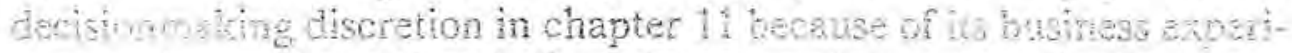
ence and sxpertise. They believe, however, that courts should glay a much more active (and less deferential) role if the debtor in possession's decision is likely to impose a large adverse impact on one constituency or threatens to dominate the outcome of the entire reorganization. A sale of substantial assets prior to confirmation illustrates the latter concern and thus is a context in which courts should conduct a more searching review than with respect to most other business decisions. ${ }^{137}$

Although the cases and this Nimmer-Feinberg analysis have managed accurately to pinpoint the symptoms, they miss the mark with their cure for the section 363 threat. Consider that outside of bankruptcy, sales of most or all of a firm's assets constitute a fundamental change. Recognizing that managers should not have ultimate authority over fundamental decisions because their decisionmaking incentives are inferior to those of the residual owners of the firm, state corporation statutes require that such sales be subritted to a shareholder vote. ${ }^{133}$ Nimmer, Feinberg, and the cases correcty recognize a similar problem in chapter 11. But the solution cannot be for courts to step in and more closely scrutinize the reasons for proposing the sale. Unformately, judges have even worse decisionmaking incen. tives than managers: because judges have no financial interest in the enterpise and are immune from the market forces that constrain the agency costs of decisionmaking by managers, they are much less sulted to play the role of final arbiter with respect to a crucial business decision than to perform traditionally judicial functions, such as policing misbehavior. ${ }^{139}$

135 See, e.g., Naron \& Wagner, 88 B.R, at 88.

136 Mimmer zeinberg, supra note 3, at 15-20.

137 (3) at $19-20$.

138 E.g., Del. Code Ann. tit. 8, § 271 (1983).

139 Baird, supre note 2, at 136-37. Kenneth Scott argues that courts are poorly suited to review tusincss judgments made by the firm's managers but well suited to consider alleged 
This rensoning siggests that sales of substanial assets should be decided by s wote, rather than by a judge. Because chapter 11 locates the franchise in the plan process, one could argue that such sales should not ba permitred prior to the plan's confirmation. Only if the salas are rat ind ont under chapter 11's votng movisions wil! the arected paris including the firm's residual owher, have the fural sevis + ito

Proponenis of the current regime point ont that reguting all asset saies to take place in connection with the plan process ignores the fact that an earier sale sometimes is in the best interests of everyone, as when the Arm's assets could decline in value. Recognizing that in some cases all interested parties will prefer a preconfirmation sale does not mean that enhanced judicial scrutiny under section 363 is the best yay to effect such sales, however. Notice that selling the firm's assets prior to confirmation in effect creates a liquidation: it reduces the parties' interests in the firm to interests in a pot of cash. ${ }^{14 i}$ Arguably, prohibiting preconfirmation sales in chapter 11 would merely force the parties explicitly to convert the case to chapter 7 and conduct the sale in that context. As long as the decisionmaking appara-

conticts of interestst accordingly, he concludes that the duty of loyalty should be strengthened and the daiy of care eliminated outside of bankruptcy. See Kenneth E. Scott, Conporation Law and The American Law Institute Corporate Governance Project, 35 Stan. L. Rev. 927, 946 (1933) see also Shlensky v. Wrigley, 237 N.E.2d 776, 779 (111. App. 1968) ("it is not the cours" [taction to resolve for corporations questions of policy and business management") fciring Davis v Lotisville Gas \& Elec. Co, 142 A. 654, 659 (Del. Ch. 1928)); George M. Coher, The Negligence-Opporinism Tradeoff in Contract Law 65-68 (unoublished manuscript, on file with the Virginia Law Review Association) (discussing courts' ability to deter oyportunism). The text makes the same point that within bankruptcy, coun involvement stotid be mintmized-not expanded-whete a business decision is at issue.

140 Notice thot the parties' right to object to a proposed sale (as provided by the current regutement of notice and a hearing) is not an adequate surrogate for the tranchise. Even if we put to ane side the limitations of bankruptey judges as the final arbiter, the right to object is soruehing very distereni from having the final say. The parties mighi, for example, vote against a proposal that is sufficiently reasonable to withstand legal oijections.

if A prticonimation sale inevitably leads to strict adherence to the absolute prionity rile because reducing the assets of the firm to cash eliminates any leverage junior croditors and shareholders might otherwise have. Consider the posture of Lionel and Bratiff. See supra note 129. One suspacts that in Lionel the equity holders' opposition to the sale was based on the realization that the sale would eliminate their prospects for recovery. In Braniff, the same realization probably caused junior creditors and shareholders (or Branif's managers, acting on their thall to insist that the memorandum of sale include provisions ensuring that their interests would survive confirmation. See id. 
fas of chapter $7^{141}$ is superior to judicial review of asset salas, atht action would improve the current regime.

At least two factors counsel against conversion of cases to chapter 7 from chapter 11 in this concekt. First, conversion may be costly ant contentious, The added expense might chill resort to even dentl. desirable eariy saies. Second, there may be cases in which the parti. wish to sell most of the firm's assets but not to liquidate (based, pe:haps, on their view of the value of the firm's remaining assets), Prokibiting preconfirmation sales would eliminate this option bepange firms would be forced to choose between complete liquictation under chapter 7 and forgoing an early sale under chapter 11.

A better solution would permit preconfirnation sales of substantiat assets in chapter 11 but transfer authority to a more effective dectsionmaker. One way to achieve this goal might be to amend the Bankruptcy Code to compel a vote by all claimants and shareholders prior to approval of any preconfirmation sale of most or all of a fim's assets. Though such universal suffrage seems to make sense from a contractual safeguard perspective, because every constituency is vul. nerable in chapter $11,{ }^{144}$ this framework would probably prove unworkable. In contrast to the vote on a reorganization plan, where the deemed acceptances rule tends to focus the voting and where the cramdown provisions provide a means of confirming plans that one or more classes rejects, preconfirmation asset sales would require approval of the appropriate majorities of every class. ${ }^{145}$ The necessity of achieving consensus would magnify the risk of strategic behavior and would significantily limit the parties' ability to effect a desirable preconfirmation sale. ${ }^{146}$

142 This is discussed in greater detal infra Par inI.A.3.

14. An example of this might be a large, diversified ousiness that wished to seli its uppliances division to help finance the soaling down and teorganization of its eore business of processed foods.

1.4 See supra Part Il.B.2.

i4s There is no obvious way to effect a compromise solution. Whereas impaired classes that vote against a reorganization plan are protected (albeit imperfectly) by the absolute priority rule, see Bankruptcy Code $51129(6)(2)$, and dissenters must be given at least the liquidation. value of their ciains, id. $\$ 1129(\mathrm{a})(7)$, the decision whether to approve a saie of rubstantiat assets is an unqualifiable, binary choice.

146 Another possibility would be for the parties to participate in a single, firm-wide wotrather than a class-based vote. Such a vote could be extremely expensive, however, and wsuld present nearly insoluble problems, such as the question of how to weight the woles of the various claimants and interest holders. 
Atcriatively, the ultimate dectoion could be entrusted to the single class of creditors who are identiled as the true residual owners of the firm, just as outside of bankruptcy firms give the vote to a single class of common shareholders to reflect their starus as residual owners of a whyent frm. Limitivg the frachise in this faghion would ensure both a manageale vote and that decisions ba made by the constituency with the best decisionmaking incentives. The most obvious difficulty with inporting this strategy into the bankryptcy context is determining who the residual owmers are. In the wnusual case where a firm is solvent when it fles for bankruptcy, sharcholders are the residua! owners; otherwise, the residual owners are those creditors whose priority status leaves them immediately below the insolvency line. The residual ownership class could be identified if the Code were to provide for a valuation of the firm at or shortly after the filing of the chapter 11 petition. But such a valuation would be costly and would consume both physical and temporal resources at a time when both typically are at a preminm. Moreover, as the fortunes of a bankrupt firm rise or fall during the course of a chapter 11 case, the firm's residual owner could change. ${ }^{147}$ It is thus far from clear when or how the decisionmaking class should be chosen. ${ }^{148}$

Finally, the law could designate a particular class as the sole voting class. Adopting a blanket rule would eliminate the need for a costly valuation. Moreover, by defining the voting class relatively broadly, by vesting the vote in unsecured creditors generally, for example, rather than some subcategory of unsecured creditors, the danger of choosing the wrong class as voters, as well as the danger that the residual class could change while the case is pending, conld be mini-

147 The recent chapter is case involving Allegheny laternational is ilhustrative. Shorty after the firm filed for bankruptey, an auction developed that at one point would have resulted in payment in full to both senior and unsecured creditors. Thereafter, the auction collapsed and the firm's value began to deteriorate. See, e.g., Clare Ansberry, When Will SomebodyAnybody--Rescue Battered Allegheny?, Wall St, 1., April 19, 1990, at A1. By the time a plan finally was confirmed nearly two yeats later, the value of the firm had fallen precipitously.

146 Lopincki and Whitford cite concerns of this sort as evidence that the residual ownership analysis is uitimately untenable, at least with respect to the related question of to whom ntassagement's fiduciary duties should be owed, Lynn M. LoPucki \& William C. Whitford, Corporate Governance in the Bankruptcy Reorganization of Large, Publicly Held Corporations $92-97$ (1991) (unpublished manuscript, on file with the Virginia Law Review Association). The third approset discussed in the text can be seen as a response to these Bifîculties. 
mized ${ }^{1 * 9}$ Certainly this approach is imprecise. Allowing every unsecured creditor to vote would mean that the true residual ciess of misecured creditors, as well as nonresidual classes of unsecursd credifors, would be free to participate in the vote. Notwithstanding its ingtions, however, the benefits of a clear rule outweigh the costs of ctrempting to determine precisely the firm's residual owners. The analysis clearly suggests that it is preferable that a majority of the firm's unsecured creditors, rather than a court, approve any preconAmation sale of substantial assets, ${ }^{150}$

W/ A related question is that of who in the first instance should be entitled to propose a sale of substantial assets-that is, who should have the right of initiation. One rnight argue that the îm's residual owners should also be given the right to initiate such a proposal, rather than mereiy the right to vote on proposais presented by management, but such a rule would tindermine the managers' ability to run the corporation in chapter 11 and also might invite strategic behavior by the residual class. The current situation, in which management initiates any proposal to sell substantial assets, seems preferable. Notice that this rule mirrors the regime in place under state law. See, e.g., Del. Code Ann. tit. \&, \$ 271 (1983).

150 Conducting a vote would require disclosure and give rise to other, related administrative costs. Remember in this regard that the current regime, with its requirement of notice and hearing, see Bankruptcy Code $\S 363$ (b)(1), is not costless either. Although providing notice and a hearing is probably less expensive than conducting a vote, the advantages of yesting decistonmaking authority in the residual class, rather than in a bankruptey judge, vould seem 10 outweigh any differential. Moreover, such votes would not be necessary in every case, only in the relatively infrequent chapter 11 case where management proposes a preconfirmation sale of substantial assets.

Another potential objection stems from the observation that unsecured creditors' decisionmaking incentives are skewed in chapter 11. Although unsecured creditors are likely to be the firm's residual owners, their residual status differs from that of shareholders outside of bankruptcy in that their upside potential is fixed. Whereas shareholders are entitled to the entire residual outside of bankruptey, in bankruptey unsecured creditors are entitled to the amount of their claims only, even if the firm's fortunes improve dramatically and the reorganized firm proves to be worth much more than the total of the claims. Based on similar ressoning, LoPucki and Whitford argue that managers should not manage on behalf of either shareholders or creditors alone in chapter 11 because their strategies will be foo risky if stercholdet-oriented and too risk adverse if creditor-oriented. LoPucki \& Whitford, supra Fole 148, at 18, 113-14.

For at least two reasons, these observations do not alter the analysis in the text. First, breause firms fortunes usually will not improve enough in chapter 11 to make full compensation of unsecured creditors a realistic possibility, unsecured creditors decisionmaking incentives should not be skewed in any significant way. Second, unsecured ereditors often receive a significant portion of the equity of the reorganized company. See, e.g., Lopucki \&. Whitford, supra note 84 , at 165 . As a result, they often are the firm's future shareholcers, and will therefore share in any postconfirmation upside. In short, the skewing effeet seems likely to be more theoretical than real. 


\section{A Nute on Strategic Choice}

Commentators have noted that the managers of a firm outside of benkruptey sometimes attempt to ensure passage of a proposal by Wwathrg the proposal with a "3testeren" In the dugl olass recapital. hatwh context, for instance, mangen my promise to increase divi" denes if the recapitalization is adopted toritrey Gordon has used gane theory to show that such proposals force shareholders to make a stuategic choice: if they wish to receive the fpotentially wealth increasing) dividends, shareholders must agree to the (possibly wealth decreasing) recapitalization. ${ }^{152}$ The consequence of the shareholders' diemma, he argies, is that even undestrable recapitalization proposals are likely to pass. ${ }^{153}$

Interestingly, the claimants and interest holders of a chapter 11 debtor may face an analogous strategic choice if a proposal to sell the farm's assets to a third party is coupled with the vote on a reorganization plan. For example, suppose a third party proposes to purchase the firm for 31 million in connection with a reorganization plan that will pay subordinated bondholders $30 \%$ of the face value of their ctains. Assume that all parties know the firm's assets actually are worth $\$ 1.2$ million. If the subordinated bondholders believed that they would receive only $25 \%$ of the value of their claims under a strict absolute priority rule plan and that the best they could hope for under any plan was $30 \%$, the class would be foolish not to approve the proposal. Other classes might be confronted with the same type of ditemma. As such, the parties' desire for the best possible distribution conld cause them to approve an inefficient sale. ${ }^{154}$

151 See Gordon, supra note 11 , at 48 ; Jefirey 24 . Gordon. The Mandatory Siructure of Corperate Law, 89 Colum. L. Rev. 1549, $1577-78$ (1989).

192 Gondon, supra note 11 , at 47-60.

[57 Insider ownership of significant percentages si the firmis' stock and credible threats by matagement also appear to play a role in shareholders acceptance of these proposals. Id,

15s Strategic choice issues appear to have played an important role in the collapse of the chapter 11 auction of Allegheny Internationi. See supta note 147. During the auction, the debtor :wice accepted bids from Donadson, Lufkin \& Jenrette Securities, but was persuaded on both occasions by the other puincipal bidder, Pat Lexy, to reopen the bidding process. It was not at all clear that the Levy bids offered greater watue. Instead, the key characteristic of the Levy bids may have been that they promised benter treatment for the shareholders of Allegheny. As a result, shareholders (through their committee) put significant pressure on the directors of Allegheny to consider Levy's offers, See Ansberry, supra note 147, at A? (describing the events of the Allegheny case). 
The parties raty contron a version of this striegic chaice Alomme in every chapter II case. Even if the reorganization proposal tues not involve ant explioit sale, in weighing whether to approve a plan ead clas must compare the amount it might receive under a sthot ghsothe pronty rule plan whe the anount it would rewive andm the

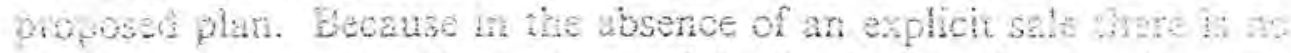
powigus way to wibunde the issue of the firm's overa!l wetue fon the isske of a given class' share, strategic choice is inevituble. ${ }^{155}$

But what about cases hyvolving an explicit sale? Remuing that any sale of the firm's assets intact be conducted separately from the reorganization plan itself might dramatically reduce the strategic choice problem. In the exatnple, the parties could be required first to sell the firm's assets to the third party and only then to determine the distribution to each class. Because the parties (we have assumed) know the assets are worth $\$ 1.2$ million, they presumably would reject the inferior offer if it were unbundled from the question of distribution.

The drawback of such a rule is that it would chill managers' efforts to seek out and propose third-party sales. ${ }^{156}$ A preconfirmation sale reduces the firm's assets to a pool of cash, eliminates uncertainty as to the firm's fortunes and the value of its assets (the principal source of bargaining leverage for lower priority claimants and interest holders) and this ensures strict adherence to the absolute priority rule. Senior creditors would be cashed out first, and junior creditors and shoreholders often would receive little or nothing. As a result, rnanagers with interests aligned with those of the junior creditors or shareholders might forgo an otherwise desirable sale. ${ }^{157}$

155 See Douglas Baird \& Thomas Jackson, Corporate Reorganizations and the Treatment of Diverse Dwhership Interests: A. Comment on Adequate Protection of Becured Creoitons in Bankruptcy, 51 U. Chi. L. Rev, 97, 108 (1984) (arguing that bankruptcy law "Should aim to keep the asset-deployment question separate from the distributional question, and to have the deployment guestion artswered as a single ownet would answer it"). The gtrategic choice isste is complicated by plan proponents" nse of diffeult-to-value debt and cathy sevurities.

136 See supra notes $92-97$ and accompanying text for a elosely related anaiysis wo whether shareholders should lose their right to vote on a reorganization plan even if the irm is olearly insolvent.

157 See LoPucki $\&$ Whitord, supra note 108 (concluding that managars of putilidy held fims were sometimes shareholder-ortented in chapter 11 , and sometimes crecitomented). For similar reasons, managers may also be hesitant to propose precontirnation asset stes under current law. Unless the lim is hopelessly insolvent (and the lower classes thos unitkely to receive any distribution under any plan), the proposal sonehow also guarantees a recovery for junior crediors and shateholders, or the managers' interests are, for some other resson, no 


\section{The Analogy to Creditors Election of the Chapter 7 Trustee}

My proposal to put preconfirmation sales of substantial assets to a yote by the unsecured creditors already has been adopted (at isent in pard in chapter 7 liquidation cases. In particular, section 702 Jesignates unsecured creditors as the voting class, with the right to select the irustee by a majority vote (in amount) of the unsecured creditors who yote, if the holders of twenty percent in amount of these clains have requested such an election. ${ }^{158}$ Otherwise, the interim trustee continues to serve as trustee. ${ }^{159}$ Of course, this mechanism is less direct than my proposal to permit unsecured creditors to decide whether to approve a preconfirmation sale of substantial assets. But the unsecured creditors' more limited role in chapter 7 is easily explained. Chapter 7 usually consists of a piecemeal liquidation of the firm; ${ }^{160}$ rather than selling the firm as a going concern, the trustee conducts a series of partial sales. Educating the unsecured creditors as to the merits of each of these partial sales, and submitting each to a vote no matter how trivial the sale, would be as unwieldy as providing for shareholders of a publicly held corporation to oversee the ordinary operations of the firm. Just as shareholders elect directors (who in turn appoint officers) to be their representatives with respect to the firm's ordinary affairs and vote directly on fundamental issues only, so unsecured creditors, the firm's residual owners in bankruptcy, leave the day-to-day business of a chapter 7 liquidation to their chosen representative, the trustee.

But what if the trustee in a given case does not intend a piecemeal liquidation of the firm? What if she proposes a third-party sale? This possibility brings the discussion full circle. The analysis of preconfirmation sales of substantial assets in the chapter 11 context would be in such a situation equally applicable in chapter 7. Thus, the trustee's pioposal to effect a third-party sale in chapter 7 can be seen as a fundamental issue that should be put to a vote of the unsecured creditors,

longer aligned with those of the shareholders or lower priority creditors, managers are tnlikeiy to propose preconfirmation sales.

158 Bankruptcy Code \$ 702(b).

159. Id. $\$ 702$ (d).

100 Baird, supra note 2, at $131,146-47$. Baird explains the rarity of sales of firms intact in chapter 7 as resulting from the nature of the chapter 7 trustee's powers, which tre designed with piecemeal liquidation in mind, and from the sacrifice of certain tax benefits if a firm liquidates ia chapter 7. See LoPucki \& Whittord, supra note 84, at 171 n, 104. 
as should a preconfirmation sale of substantial assets in chapter 11; likewise, a proposal by the directors to sell most or all of a firm's assets would trigger shareholders' voting rights outside of bankruptcy.

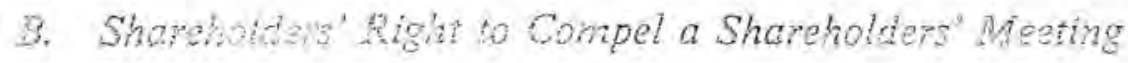

1. Judicial and Acudemic Treatment of Shareholders' Meeting Reguests

Given the dramatic increase in chapter 11 cases involving publicly held firms, ${ }^{161}$ the most important of the chapter 11 voting issues may be shareholders' right to compel a shareholders' meeting. In the last several years alone, the issue has arisen in three major bankruptcy cases.

In Saxon Industries v. NKFW Partners, ${ }^{162}$ the Delaware Supreme Court, reasoning that shareholders are entitled to elect and replace directors absent extraordinary circumstances, held that Saxon's shareholders should be able to compel a shareholders' meeting. ${ }^{163}$ Shareholders were equally successful in vindicating their claimed right to compel a shareholders' meeting in In re Lionel. ${ }^{164}$

In $1 n$ re Johns-Manville Corp., ${ }^{165}$ on the other hand, both the bankruptcy court and the district court rejected the Equity Committee"s efforts to compel a shareholders' meeting, each court voicing concern that a shareholders' meeting would jeopardize a reorganization proposal that had been three years in the making. The United States Court of Appeals for the Second Circuit reversed because it was not clear whether the district court had denied the meeting as a result of

(6) Sharon Reier, Bankruptcy Boondoggle, Fin. World, Oct. 16, 1990, at 36 (noting that 13 of the 25 largest barkiuptcies have occurred in the last two years).

162488 A.2d 1298 (De!. 1984).

163 Id. at $1301-03$.

164 Lionel Corp. v. Commitiee of Equity Sec. Holders of Lionel Corp. (In re Lionel Corp.), 30 B.R. 327, 330 (Bunkr. S.D.N.Y. 1983). In allowing the Equity Committee to pursue its Inceting request in the Delaware chancery court, the bankruptcy judge stated that "if the defendants are able to elect a new board it may be that the reorganization here will ake an enticely different turn." Id. (remarking upon the court's observation at an earlier hearing of the case). The chancery court ordered Lionel's directors to eall the requested meeting. Committee of Equity Sec Folders of the Lionel Corp. v. Lionel Corp., N.Y.L.J., June 28, 1983, at 6 (N.Y. Sup. Ct. 1983).

16952 B.R. 879 (Bankr. S.D.N.Y.), af'd, 60 B.R. 842, 852 (S.D.N.Y.), rev'd, 801 F.2d 60 (2d Cir, 1986). 
the Equity Commitse's use of the reguest as a strateren wot, or because the judge had detemined that the commitree wished to "torpedo" the reorganization, "to The latter stuation warrans denial of the request, the cour hald, but the forner does not, as shrobolders have the right to a meshig absent a showing the mesting woult con-

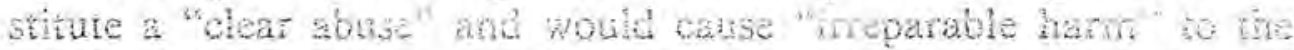
corporation. ${ }^{167}$ On readad, the bankrupicy court complied an exhaustive record in supgot of its original determination and again enjoined the Equity Commitree from seeking a meting ${ }^{\text {in }}$

These cases suggest that courts continue, in bankmptcy, to recognize shareholders' state law right to hold a meeting. ${ }^{169}$ INonetheless, courts will interfere with shareholders' efforts to replace and clect directors if, as appears to have been the case in Johns Manville, the shareholders ciearly have overstepped their bounds. ${ }^{170}$ irost commentators have agreed that bankruptcy does not and should not affect shareholders' right to hold a shareholders' meeting to replace or elect directors. ${ }^{171}$ For example, Michael Gerber's thoughtful commentary

\footnotetext{
166 Jorks-Manville, 301 F.2d at 64-68.
}

167 Id.

168 In re Johns-Manvilie Corp, 66 B.R. 517 (Bankr. S.D.Y.Y. 1986).

169 Less than two years after the Johns-Manville decisions, the United States District Coar: for the Westem District of Pemsylvania decided a fourth shareholders' meeting request case in favor of a group of preferred shareholders who sought to make tise of the voring rights they had acquired when Allegheny international stopged paying dividends prior to bankruptcy. Following their victory, the preferred shareholders conducted a proxy contest and, at the subsequent meeting, placed live directors on the twelve-person board. Tin re Allegheoy Int'! [1987-1989 Transfer Binder] Bankr. i. Rep. (CCH) ग7 72,328 (W.D. Pa. Miay 31, 1988).

Pre-Code decisions permitting of compelling shareholders' mectings inchude Harvey $v$. Plankinton Bldg. Co, 138 F.2d 221 (7th Cir, 1943); in te. I.P. Linahan, Inc, 111 F.2d 590 i2d Cir. 1940); Van Siclen y. Bush, 78 F.2d 662 (2d Cir. 1935); Taylor v. Philadelphia 2 Reading R.R., 7 F. 381 (E.D. Pa. 1881). But see Fortgang \& Mayet, supra note 99, at 65-68 (arguing that shareholders' meetings were permitted in pre-Code cases enly where bolding a ineeting would have had no effect at all on ithe reorganization).

170 Pre-Code cases denying meeting reauests include in re Potter Instrument Co., 593 F.2d 470, 474 (2d Cir. 1979) (derying meeting sought by large stherinoluer bent on "smash[ing]" the company); Haugh $v$, Industries, Inc., 44 F.2d 425 (2d Cir. 1964) (affirming stay of meeting pending resolution of a Chapter $X$ case that was likely to be dismisscai); Grasetli Chem. Co. v. Aetna Explosives Co., 252 F. 456 (2d Cir. 1918) idenying preferred sharehoiders request for a meeting where preferred shareholders' voting rights arose only after the uppointment of a receiver and were litely to be temporany); Alrac Corp. v. Clement, i Banki. Ct. Dec. (CRR) 1504 (Bankr. D. Con. 1975) (denying meeting where request eame aftet confirmation of a reorganization plan inat would give suajority control to current creditors)

171 An article co-authored by Chaim Fortgang and Thomas Mayer is a conspicuous exception. Fortgang \& Mayer, stipra nore 99. Fortgang and Miayer read both the Bankruptcy 
wh Whn-Manville notes that sharebolders right to call a meeting is an important bargaining chip for shareholders in bankrupicy. ${ }^{172} \mathrm{He}$ argues that their retention of this privilege is bonsistent both with the barkrapecy policy of incorporating state law in the absence of indicafons to he contrery, and with the dinfters attempit to encomage con-

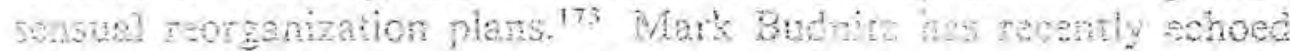
these concerns. ${ }^{1 / 2}$ He argues that the federal proxy rules support

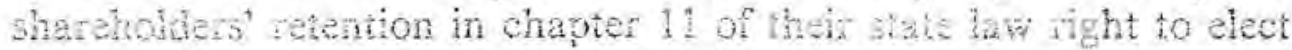
and replace dinectors because their principal convern is investor protection. 173 On the other hand, he recognizes that the drafters of the Bankruptcy Code expressed a desire not only to protect investors, but also to oromote speedy reorganization. ${ }^{176}$ To reconcile these concerns, Budnitz proposes an elaborate balancing test that presumes in most cases shareholders should be entitled to elect and replace direcfors as they wish, ${ }^{177}$

Neither the case law nor the commentary, however, provides a persuasive response to the question of why shareholders should retain the right to hold a meeting if the corporation is insolvent, as most chapter 11 debtors are. ${ }^{178}$ Both courts and commentators suggest that share-

Code and pre-Code case law as precluding sharehoiders from calling a sharehoiders' meeting in the chapter 11 context.

172 Michael A. Gerber, The Election of Directors and Chapter 11-The Second Circuit Tells Stockholders to Waik Softly and Carry a Big Lever, 53 Brookiyn I. Rev. 295 (1987).

173 1̇ं.

174 Mart E. Budnitz, Chapter 11 Business Reorganizations and Shareholder Meetings: Will the Meeting Please Come to Order, or Should the Meeting be Cancelled Altogether?, 58 Geo. Wash. L. Rev, 1214 (1990); see also Anna Y. Choa, Corporate Governance in Chapter 11: Electing a New Soard, 65 Am. Bankr. L.J. 559 (1991) (Congress intended chaptet 11 to salvage value for shareholders and did not intend to deprive sharehoiders of insolvent films of the right to siect directors).

175 Budnitz, supra note 174 , at $1225-27$.

176 Id. at $1233-34$.

in id. at 1255.66. Dudnitz suggests that courts shodld compre the berents of holding a meeting with what he describes as "major harns" and "minor barms." Major hamms include concerns sucio as the stage of the case, abuse of the shareholder-tirector relationsiip, and cost (where the debtor is seriously low on funds). Minor harms include the threat and consequences of delay, and the availability of altematives to a shareholders' meeting. In his vieg, minor harms are insufficient, by themselves, to warrant denial of a meeting request.

178 Unlike Buonitz, Gerber does not suggest thut the firm's insolvency should never be a factor. Tather, he acknowledges that "[t]hete wili be cases in which a debtor is so obviously ... insolvent that experts can agree that stoekholders have no equity .... and no prospect of ever having any," and that meeting requests should be denied in such a context. Gerber, supra isote 172 , at $35 \%$; ef Budritz, supra note 174 , at 1248 -49 directors of an insolven firm have a continuing fiduciary duty to shareholders). 
holders need this privilege as leverage in the negotiation process, regardless of whether the firm is insolvent; this is costly, howeyer, especially considering that the shareholders' interest is much more attenuated in an insolvent firm. ${ }^{179}$

One cost is that shareholders may (and do) call wareholders' neetings opportunistically. Consider the effect of strertholders' 3tatus in bankruptcy. Because chapter 11 debtors usuaity are insolvent, an immediate liquidation would leave shareholders with acthing. Moreover, shareholders may not expect to receive much even if the firm is reorganized. ${ }^{180}$ Thus, shareholders have little to lose when they invoke their right to call a meeting and are unlikely to be constrained by the possibility that their use of this tactic as a bargaining tool could jeopardize the entire reorganization.

Several of the decided cases support these suspicions. The Equity Committee in Johns-Manville requested a meeting for the avowed purpose of imploding the current reorganization plan. ${ }^{181}$ The Committee's willingness to unsettle the negotiations, even at the risk of jeopardizing any prospect of eventual reorganization, appears to have stemmed directly from the probability that shareholders' interests would have been significantly diluted under that or any other plan. Similarly, in In re Potter Instrument Co., ${ }^{182}$ a $45 \%$ shareholder sought to compel a shareholders' meeting for the purpose of electing directors who would contest a chapter 11 arrangement that had been approved by ereditors, notwithstanding that such a meeting might sound the "death knell" to the debtor firm. ${ }^{183}$

The "clear abuse" test relied on by the courts is an insufficient response to this problem because shareholders' incentives are system" atically, not just occasionally, flawed. Moreover, any directors

179 In addition to arguing from a positive perspective that shareholders' continued right to call a meeting, despite insolvency, is consistent with chapter 11's relaxation of the absolute priority rule, Gerber suggests that permitting shareholders to retain this bargaining toot is unproblematic because it merely effects a redistribution from higher priority creditors to shareholders, without affecting the size of the overall pie. Gerber, supra note 172, at 343. Baird and Jackson, on the other hand, have argued that redistribution in bankruptcy by its very nature ultimateiy may reduce the size of the pie. See, e.g., Baird \& Jackson, supra note 155; Jackson, Creditor's' Bargain, supra note 2, at 860-71.

180 See Jackson \& Scott, supra note 89 , at $158-59$.

181 Johns-Manville, 60 B.R. at 852 .

182593 F.2d 470 (2d Cir. 1979).

15.3 Id. at $474-75$. 
elected by shareholders also will have suspect decisionmaking incentives. Thus, the effect of permitting a shareholders' meeting would be to put decisionmaking authority in the hands of directors who do not represent the best interests of the corporation as a whole.

the conclusion that directors selected by sharehoiders will shave this sonstimency's poor decisionmaking incentives may seem subjsct to dispute. Arguably, even directors elected by the shareholders will be constrained in that once a firm enters bankruptey, directors owe Aduciary duties to creditors as well as to shareholders. In theory. then, directors cannot simply side with shareholders if shareholders interests conflict with those of creditors and of the firm as a whole. ${ }^{134}$ But this response is hardly satisfactory. First, it has not been empirically shown that directors who are chosen and elected by shareholders will truly embrace the interests of the estate as a whole once they haye taken office. ${ }^{185}$ One suspects, to the contrary, that such directors will continue to represent shareholders' interests, although the fervency of this favoritism may be limited at the margin by recognition of their duties to creditors and the estate. ${ }^{186}$

Second, even if directors elected by shareholders were capable of putting their loyalty to one side, it seems ironic that shareholders, a constituency whose decisionmaking incentives almost always will conflict with the goal of maximizing the value of the firm, are given the right to choose the debtor's directors. In short, if one single constituency should be entitled to call a meeting in chapter 11 to replace the firm's directors, shareholders seem an unlikely choice.

Even the most persuasive of the arguments marshaled on behalf of granting shareholders' meeting requests proves problematic on closer inspection. As noted, both courts and commentators place heavy

184 See, e.g., Budnitz, supra note 174, at 1248-49.

1.55 The chopter 11 experience of Allegheny International reinforces the suspicion that they wiil not. The five directors who were elected by the preferred shareholders in that case were perceived by the parties to be advocates, first and foremost, of the preferred starehoiders who clected them, notwithstanding the directors' duties to creditors and the estate as a whole. The identification was so strong that these directors were often referred to as the "Spear Leeds directors" (Spear, Leeds \& Kellogg being the preferred shareholder most responsible for their eiection). See Ansberry, supra note 147, at A8.

186 Lo:ucki and Whitord conclude that management's allegiances are uncertain in chapter 11. See LaPucki \& Whitford, supra note 148, at 81-84. However, none of the cases in their siudy appears to have involved the replacement of directors during bankruptcy with new directors elected by the debtor's shareholders. It seems likely that, as in Allegheny, such. dirtetors would (at least nominally) be beholden to the constituency that elected them. 
emphasis on the fact that shareholders' right to elect drectors is an important safeguard outside of bankruptcy. Taking away this pretogative, they argue, removes one of few mechanisms by which shareholders are able to minimize the threat of opportunstr by the firm. ${ }^{18 t}$ But shachotders are not the only exposed parties. Recoll that the firm's other constituencies mast also relinguih thetr contractual she guarts in chapter $11 .{ }^{\text {igz }}$ Thus, removal of shateholder' right to conpel a shareholders' meeting can be seen, in context, as consistent with the pervasive restructuring of other parties' contractual safeguards that takes place in chapter $\hat{1} 1$.

\section{Who Should the Voters Be and Inhen Should Elections Be Held?}

If shaxeholders should not be permitted to compel a meeting, who should hold this right? Again there are two possible answers: either all constituents or the true residual owners of the firm.

As in the discussion of asset sales, focusing on contrachual safeguards might point toward the choice of a universal franchise: because each constituency is exposed in bankruptcy, arguably each should have a voice in governance. ${ }^{189}$ Universal suffrage in the asset sale context is administratively infeasible because such a system would require the approval of every class for a sale of assets. Interestingly, universal franchise seems, at first, to hold more promise in connection with the election of ärectors. In particular, the Bankruptcy Code could eliminate the necessity for unanimous approval, or for weighting each claimant or interest holder's vote, by permitting each constituency to elect a preascertained number (or percentage) of directors. ${ }^{109}$

This approgch succeds in giving each constivency representation, and thus a voike, on the board, but it suffers from significant shortcomings. Not only would the representation of each constifuency be

187 Budntz, supra note 174, at 1248-50; Gerber, supra note 172, at 341-48; Mark A. Cleaves, Comment, Stockholders' Rights in a Corporate Democracy Under Detaware Corporation Law During Bankruptey: Saxon Industries, Inc. "NKFW Pankers, il Del. 3 . Cotp. L. $321(1996)$.

18. See supra notes $74-87$.

134 See supta notes $144-46$ and accompanying text.

10n Gf. Del Code Ann. tit. $8, \& 141$ (d) (1983) (authorizing frrms to provide for a zlassified board outside of baktuptcy). 
diluted by the presence of directors beholden to other classes of claimants, but the directors' efforts to serve their respective constituencies would make decisionmaking consensus virtually impossible. ${ }^{191}$

Thus, though universal sufrage offers more intriguing possibilites in the context of a directorial election than it did with respect to stis of substantial assets, limiting the franchise to the firm's true resictuat owners-presumably its unsecured creditors-emerges once again as the better choice. As before, the chier virtue of such a rule is its effect on decisionmaking incentives. The rule also avoids the kinds of administrative difficulties that make universal suffrage iargeiy unworkable in the absence of a focusing device like the deemed acceptances rule. ${ }^{192}$

Selecting unsecured creditors as the appropriate voters still leaves the question of when elections should be held. Consider first the possibility that directors elected by shareholders might continue to favor shareholders' interests after the firm filed for chapter 11 relief, notwithstanding that these interests would be then merely speculative. One could plausibly argue, based on this perception, that the firm's directors should be replaced, or at the least an election held, at the commencement of every chapter 11 case in order to ensure that directors have proper decisionmaking incentives. ${ }^{193}$

But holding an election and replacing the firm's directors at the start of every bankruptcy would be both cumbersome and expensive. One reason the Bankruptcy Code permits current management to remain in place as the debtor in possession, with virtually the same rights as a trustee, ${ }^{194}$ is to minimize disruption to the firm's ongoing business. Moreover, if current managers feared that new directors

19] Martin Lipton and Steven Rosenblum make a somewhat similar point in arguing that, outside of bankruptcy, directors should represent ill corporate constituencies rather than jusi shareholders, but that "[i]t is not necessary, and indeed it would be divisive, to elect separate classes or groups of directors to represent the various corporate constituencies, or to have any constituency have a separate special right to nominate or advise on the nomination of directors." See Ivartin Lipton \& Steven A. Rosenblum, A New System of Corporate Governance: The Quinquennial Election of Directors, 58 U. Chi. L. Rev. 187, 247 (1991).

192 See supra note 66 and accompanying text.

193 Such a rule would be similar in many respects to the contractual provisions that give voting rights to lenders or preferred stockholders if the firm defaults on an obigation ar considers a particularly risky undertaking. The notion in both cases is that default or if bankruptcy petition is likely to reflect a change in risks such that shareholders no longer are the appropriate decisionmakers for the nirm. See Easterbrook \& Fischel, supra note 6, at 404

194 Bankruptcy Code $\$ 1107$. 
might irmediately replace them, notwithstanding the business continuity contemplated by the drafters of the Bankruptcy Code, they would have a perverse incentive to delay entering chapter $11{ }^{195} \mathrm{As}$ a. result, wholesale turnover at the stat of the bankruptey case is an Wnatractive option. ${ }^{\text {wo }}$

The same concerns also suggest that the nim's residual owners should not have an automatic right to compel a meeting. The Bankruptcy Code should provide some opportunity for the replacement of directors, however, because at times mismanagement or stalemate will make an election desirable.

One possibility that could effectively balance these concerns would be to adopt the "for cause" standard, used elsewhere in the Bankruptcy Code to justify replacement of management with a trustee. ${ }^{197}$ The "for cause" requirement would establish a rebuttable presumption that the current directors should remain in place for the duration of the bankruptcy case. ${ }^{198}$ Because replacement of directors is a less draconian measure than appointment of a trustee, courts should and presumably would require a lesser showing of "cause" in the former context than they currently do in the latter. ${ }^{199}$ Such a rule would ensure continuity, while still providing an alternative to appointing a trustee on those occasions when the firm's management is in fact

195 Even if their jobs were secure, managers would lose the advantage of the prebankruptcy working relationship they are likely to have established with the current directors.

196 The directors themselves often do not wish to retain their positions, however, due to the significant increase in board meetings and other responsibilities that typically accompanies a chapter 11 petition. One response to this problem would be, and should be, to increese directors' compensation in bankruptcy. See, e.g., Lipton \& Rosenblum, supra note 191, at 227 (making a similar suggestion in connection with their proposal that directors be elected on a quinquennial basis). Another possibility would be to attempt to tie the directors' compensation to the success of the reorganization. In the event that directors do resign, the remaining directors themselves should fill the yacancies, as the laws of many states permit them to do outside of bankruptcy. E.g., Del. Code Ann. tit. \&, § 223 (1983).

197 Bankruptcy Code $\$ 1104(\mathrm{a})(1)$. Section 1104(a)(2) also authorizes appointment of a frustee "if such appointment is in the interests of creditors, any equity security holders, and other interests of the estate."

198. Court discretion is less probiematic here than in the context of preconfirmation sales of substantial assets because the court is deeiding only whether there will be a vote. The actual choice of directors would be made by the firm's unsecured creditors, not the court.

199 See in re Microwave Prods, of Am,, 102 B.R. 66́1, 670 (Bankr. W.D. Tenn. 1989) ("appointment of a trustee is the exception"); In re Tyler, 18 B.R. 574, 577 (Bankr. S.D. Fla. 1982) ("appointment of a trustee ... is an extraordinary remedy"). 
impeding the reorganization effort or the directors are stalemated or otherwise serving ineffectiyely.

\section{Buying a Blocking Position Within a Class of Clotins}

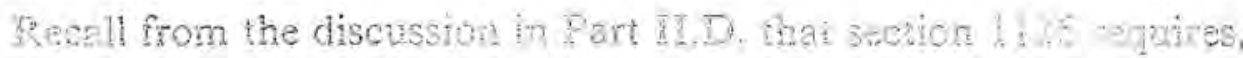
for acceptance by a class of ciatns, that a majorty in nuzber ada two-thirds in amount of the clains vote in favor of the proposed reor-. ganization plan and that this standard tends to operate like a twothirds supermajority voting requirement, 200

A two-thirds voting requirement gives any claimant who acguires claims totaling just over one-third in amount veto power over the vote of the class in question. Courts already have begun to struggle with the question of what limitations (if any) should be imposed on parties? exercise of this veto power. ${ }^{201}$ The dramatic increase in the trading of bankruptcy claims ${ }^{202}$ suggests that the issue will play a crucial role in future bankruptcies.

\section{Assertion of Veto Power in Allegheny International}

The scope of the veto power was a central issue in In re Allegheny International, Inc. ${ }^{203}$ In January, 1990, nearly two years after Alle-

200 See supra note 99 and accompanying text.

201 See infra notes 208-09.

202 See, e.g., Diana B. Henriques, Speculating on Bankruptcies, N.Y. Times, Oct. 21, 1990, §3 3, at 15; Stephen Taub, Attention Yulture Shoppers, Fin. World, March 6, 1990, at 16. Despite the apparent virtues of claims trading, such as increased liquidity and the likelihood that the purchasers of claims will take an active interest in the bankruptcy case, Fortgang ${ }^{2}$ Mayer, supra note 99 , at 4-6, courts have viewed the phenomenon with considerable suspicion. The courts' principal concern is that claims traders will take advantage of claiments who may be poorly informed about their prospects for recovery. To prevent this result, several bankruptcy courts have devised their own safeguards. See, e.g., In re Allegheny in'l, 100 B.R. 241, 243-44 (Bankr. W.D. Pa. 1988) (sellers must be given current estimates of the value of (heir claims and the right to rescind); in te Revere Copper and Brass, 58 B.R. I (Bankr. S.D.N.Y. 1985) (requiring that sellers of claims be given 30 days to rescind the sale where buyers fatled adequately to inform sellers of their options). One caurt even denied a transfer altogether, where the buyer failed to disclose its intention to propose a $100 \%$ plan, though Bankruptcy Rule 3001(e), which governs transfers, treats the court's role as largety ministerial. Int te Chateaugay (In re LTV Energy Frods.). Ch. 11 Case Nos. 863-112270/334, 402, 464 (Bankr. S.D.N.Y. Mar. 11, 1988). The newiy revised version of Bankruptey Rule 3001(e) eliminates such ad hoc measures by giving the transferor 20 days to reconsider the transfer, after which time the court must substitute the transferee for the transferor in its records. Notice that neither the old nor the new version of Bankruptcy Rule 3001(e) governs transiers of publicly traded bonds.

203118 B.R. 282 (Bankr. W.D. Pa. 2990) 
Bheny filed its bankruptcy petition and a year after an auction for the company had collapsed, the bankruptcy court approved a disclosure statement submitted by Allegheny, thus paving the way for a yote on the debtor's plan. ${ }^{204}$ Also in January, 1990, Japonica Partners filed at ampeting plen pursuant to which Japonica would take control of the aeorganized company. In an effor to ensure defeat of the debtor's flan, and to better the prospects of confirming its own plan, Japonica purchased claims sufficient to give it 2 blocking position in two slasses, the class of secured bank lenders and the senior class of unsecured claims. 205 When Japonica caused these classes to vote against the debtor's plan, thus precluding confirmation, Allegheny asked the bankruptcy court to disqualify Japonica's votes and to confirm the plan.

The bankruptcy court opinion in Allegheny points out that section 1120 (e) specifically authorizes a court to " 'designate' (i.e., disqualify) the ballot of 'any entity whose acceptance or rejection... was not in good faith, or was not solicited or procured in good faith." "206 Thus, a blocking creditor must wield her influence in good faith. The line between good and bad faith is not always clear, however. A creditor's votes should not be disqualified merely because she purchased claims (as Japonica did in Allegheny) for the purpose of defeating a reorganization plan. But a determination that a creditor's intent is unrelated to her status as a creditor of the class in question may warrant designation. ${ }^{207}$ Accordingly, a creditor can reject a reorganization plan if she expects that a subsequent plan will provide greater value, ${ }^{208}$ but not because she runs a competing business and wishes to see the debtor eliminated. ${ }^{209}$

204 id. at 286 .

205 Japonica purchased a total of $33.87 \%$ of the secured bank claims. With respect to the senior unsecured claims, Japonica purchased slightly less than the $3,3 \%$ technically necessary to establisin veto power over the class, but because many of the claimants in this class were not expected to vote, and in fact did not, Japonica held an effective veto in this class as well. Id. at $286-87$

200 Id. at 287 (quoting Bankruptcy Code $\$ 1126(\mathrm{e})$ ).

207 id. at 289 (citing In re P-R Holding Corp., 147 F.2d 395, 397 (2d Cir. 1945)).

30 Seé, e.g., Insinger Mach. Co, v. Federal Support Co., 859 F.2d 17 (4th Cir, 1988); Mokava Corp. v. Dolan, 147 F.2d 340 (2d Cir. 1945); In re Pine Hill Collieries Co., 46 F. Supp. 659 (E.D. Pa. 1942); In re Gilbert, 104 B.R. 206 (Bankr. W.D. Mo. 1989); In re Landau Boat Co., 8 B.R. 432 (Bankr. W.D. Mo. 1981).

204 See In re Macleod Co., 63 B.R. 654 (Bankr. S.D. Ohio 1985) (designating votes of three creditors employed by debtor's competitor); see also in re P.R Hoiding Corp., 147 F:2d 895 
The court in Allegheny concluded that Japonica's motyes fell into the larter category. Because Japonica appeared to have bought its clams for the purpose of asserting control over the debtor and the recrganization process, tather than to further any interest sufficiently retated to its status as a menber of the two classes of claims, the cout disqualitied Japoniea's votes and, subject to severd restrictons, contfrrmed the Allegheny plan. ${ }^{210}$

As Allegheny suggests, section $1126(\mathrm{e})$ operates as an irepressionistic (i.e., left to the court's discretion) limitation on parties' sxercise of their voting rights, Although courts appear to apply the standard in a principled fashion, ${ }^{211}$ the need for judicial oversight ${ }^{212}$ could be significantly reduced by changing chapter 11 's voting rules.

\section{The Need to Replace the Supermajority Voting Requirement With Simple Majority Voting}

Recall from Part II.D. the problem with the supermajority yoting requirement set forth in section 1126 . Supermajority voting is useful only where, as in a close corporation, there is a danger that corporate decisions will by their very nature affect majority and minority shareholders differently. This is not the case in voting on a reorganization plan, where each member of the class will receive a proportionate distribution. $^{213}$ Thus, replacing the two-thirds in amount standard with

(2d Cir. 1945) (bad faith established where purchase of claims resulted in discrimination againsi ereditors who did not sell their claims); In re Featherworks Corp., 36 B.R. 460 (E.D.N.Y. 1984) (bad fatth found where party changed yote after being paid outside of the reorganization pian).

210 in re Alieghteny, 118 B.R. at 285.

21 According to one commentator, the case law reveals two different approaches to the issue of good faith. Some courts, based on the Supreme Court's decision in Young v. Higbee 60, 324 U.3. 204 (1945), ask whether the creditor in question is seeking better treatment than that received by the other members of her class; other courts, based on $I n$ re P.R. Holding Co., 147 F.2d at 897 , find bad faith wherever a creditor is using her vote to advance "an interest other than an interest as a creditor." See Andrew Africk, Comment. Trading Claims in Chapter 11: How Much Influence Can be Purchased in Good Faith Under Section 1126?, 139 E. Pu. L. Rev. 1393, 1406-08, 1416-22 (1991) (concluding that good faith should be presumed becuuse blocking creditors piay a desirabie role in most chapter 11 cases).

212 Agan, judicial discretion is much less problematic here than in the contexi of sties of substantial assets because courts are not called upon to make business decision. insteud, they serunnize for nisbehavior, a task more in line with their competence. Cf. surta note 139 and accompanying text (management, not courts, should make business decisions).

213 See also Brudney \& Chirelstein, supra note 108, at 1357 (simple najority voling is aopropriate in arm's-lengih merger decisions where all stockholders will be treatcd aliket: 
a majoily tegurement would sacrifee little in terms of claimant protection. Morever, eliminating the supermajority requirement wowtd dinirish in two related ways the threat of hold-ap by blocking creditors. First, the majority voting requirement would signifcanty moreage the post of actuiring a biocking position by neceschathg the yerchuse of more than onehalf in amount of the class. Sacond, a party that buys more than fifty percent of the claims in a class seerns at least marginally less likely to put its investment at risk by wielding its veto hin a fashon inconsistent with the best interests of the class. ${ }^{21}$

In the close corporation context, fiduciary duty standards strike a balance between minority protection and the risk of strategic behavior. In Smith \%. Atlantic Properties, Inc. ${ }^{215}$ for instance, the court held that a minority shareholder who continually vetoed the dividend proposals made by his fellow shareholders had violated his fiduciary duty to the firm and the other shareholders. ${ }^{216}$ Section 112.6(e) performs precisely the same function-it serves as a fiduciary duty limitation on blocking creditors' use of their veto power.

My analysis suggests, however, that supermajority voting is both unnecessary and undesirable in chapter 11. This raises the question whether teplacing the supermajority standard with simple majority voting so reduces the threat of harmful behavior by blocking creditors as to obviate the need for the fiduciary duty requirement now in section $1125(\mathrm{e})$.

Because a change in the voting rules would reduce, but not eliminate, the likelihood of strategic behavior, section 1126(e) clearly should be recained. The fiduciary standard that courts apply to par-

Mitton Fartis \& Arthur Raviv, Corporate Governance: Voting Rights and Majority Rules, 20 J. Fin. Econ, 203 (1988) fderiving formal conditions under which simple majority voling is the socially optimal comorate govenance rule).

214 The concern that clamants act in the best interest of their class should not be confused with a concern for the best interests of the firm as a whole. A claimant acting in the begt interests of her class may well urge actions that, from the firm's perspective, are sutoptimal. See Baird \& Jackson, supra note 155, at 106. The problem with a claimant who tases ber vote strategicslly is that exercising the franchise in that fashion is likely to be inconsistent with the interests both of the class and of the firm as a whole.

215022 M.E.2d 798 (Mass. App. Ct. 1981).

2to Id. at 800 . The shareholder apparently favored reinvestment of earnings, rather itan dividends, bscause of the tax consequences to him of dividends. The remaining shareholders sued when he refused to withdraw his opposition even after the Internal Revenue Service threatened to, and then actually did, take action against the firm for unlawiful accumulation of earnings. 
ent-suosidiary relationships outside of bankruptcy provides a useful andogue in this respect. In the parent-subsidiary context, courts recognize that, because a parent is the principal shareholder of the subsidieny, its interests usually are aligned with those of the subsidiary. ${ }^{217}$ Anordingly, courts apply the relaxed business judgrent nale standatd to rnost decisions made by the parent as controlling shapeholder. Only when the parent "causes the subsidiary to act in such a way that the parent receives something from the subsidiary to the exclusion of, and detriment to, the minority stockholders of the stibsidiary" do courts apply the more searching intrinsic fairness standard. ${ }^{213}$

Similarly, there is no need to disqualify a blocking creditor's votes unless there is evidence that the creditor expects to receive something that the remaining members will not receive. Aladdin Hotel Co. $y$. Bloom $^{219}$ is a classic example of such a situation. In Aladdin Hotel, shareholders bought a controlling position with respect to a class of debentures for the sole purpose of coercing an amendment to the debenture indenture favorable to their interests as sharehoiders but not to the remaining debenture holders. Thus, searching scrutiny of the shareholders' use of their debenture votes was needed, although not given by the court. ${ }^{220}$

A final issue to consider is the efficacy of the section $1126(\mathrm{e})$ remedy. Because the remedy-disqualification of a claimant's vote-is injunctive in nature and does not contemplate payment of monetary danages by a controlling creditor who has breached her fiduciary duty, section 1126(e) may prove an insufficient deterrent. On the other hand, disqualification enables a court immediately to undo the damage caused by the controlling creditor. Thus, a court can disqualify votes in an appropriate case and go on to confirm the reorganization plan in question in the same hearing (if it otherwise would have passed). The bankruptcy judge can also invoke her equitable powers to augment the remedy if necessary. ${ }^{221}$ Because the equitable remedies available to the court - equitable subordination, 222 for instance-

217 See Sinclair Oil Corp. v. Levien, 280 A.2d 717 (Del. 1971).

218 id. at 720 .

$210200 F 20627$ (8th Cir. 1953).

220 The legislative history of $\$ 1126(\mathrm{e})$ condemns the result in Aladdin and suggests that its facts reflect the sort of manipulation that $\$ 1126(\mathrm{e})$ was designed to prevent. House Report, stora note 61, at 411; Fortgang \& Mayer, supra note 99, att 93 n.442.

221 Bankruptey Code \$ 105.

222 See id. \& $510(c)$ 
have precisely the same efteet as an award of motetary damages, the remedies available in connection with section $1126(\mathrm{e})$ should fully serve theit intended function.

To surnmarize, amending section 1126 of the Bankruptcy Code 10 Fesvide for simple majority tather than supermajority voting might mmish the threat of creditors' acquiring a blocking position and widing their influence improperly. The fiduciary duty standard codifed in section 1126 (e) should be retained, but need be applied anly if there is evidence that the blocking creditors' votes are a function of an interest at odds with that of the remaining members of the class. $^{223}$

223 Two recent articles have continued the discourse with respect to this issue. Chaim J. Forigang \& Thomas M. Mayer, Developments in Trading Claims and Taking Control of Corporations in Chapter 11, 13 Cardozo L. Rev. 1 (1991); Herbert P. Minkel, Jr. \& Cynthia A. Baker, Claims and Control in Chapter 11 Cases: A Call for Neutrality, 13 Cardozo L. Rev. 35 (1991).

One final chapter 11 voting issue also should be mentioned: debtors' efforts to "lock-up" the votes on a reorganization plan. See, e.g., Trans Worid Airlines v. Texaco (In re Texaco) 81 B.R. 813 (Bankr. S.D.N.Y. 1988). In Texaco, Texaco entered into a settlement with Pennzoil whereby the parties agreed, among other things, that Texaco would allow Pennzoil's claim in the amount of $\$ 3$ billion and that Pennzoil would support any reorganization plan thereafter proposed by Texaco. Id. at 815 . Rejecting Carl Icahn's argument that the agreement constituted an impermissible solicitation of acceptances by Texaco outside of the plan process, the bankruptcy court approved the settlement. Id. at 815-16.

Arguably what Texaco did was buy Pennzoil's vote. To appreciate how the lock-up agreement can be reconceptualized as a form of vote buying, consider the following reasoning. Presumably, Texaco would not have agreed to allow the full $\$ 3$ billion had Pennzoil not also committed itself to support any reorganization plan proposed by Texaco, either at the time or in the future. If Texaco would have agreed, absent Pennzoil's commitment, to altow, say, only $\$ 2.9$ bilion of Pennzoil's claim, then Texaco effectively would have paid $\$ .1$ billion for Pernzeil's vote, less a discount reflecting the likelihood that Pennzoil's claim would not be patd in full under the plan.

Commentators have split into two camps on the vote-buying issue outside of bankruptey. Compare Easterbrook 3 Fische!, supra note 6 , at 410 (vote buying creates agency costs and should therefore be prohibited) with Andre, supra note 21, at 597,619-29 (vote buying helps to diaximize shareholder wealth and does not contribute to agency costs) and Clark. supra note 21. at 793-94 (vote buying may promote desirable corporate control changes) and Manne, supra sote 21 (the market for votes promotes information-gathering and rewards those who know how to use the voting shares most profitably). On balance, vote buying in bankruptcy seens problematic under either analysis, given the danger of strategic behavior by the buyer. This is especially true where, as in Texaco, the buyer is the debtor in possession tather than an outside party. The inevitable effect of such vote buying is to solidify the control of the debtor's current managers. For example, Texaco's managers bought the vote permanently-Pennzoil was prohibited from proposing or supporting any other reorganization plan. Texaco, 81 B.R. at $81+-15$, Such practices could thwart even desirable changes in control. 
N. CoLlective ACTON Promlems AND THE ROLE OF COMMITEES IN CHAPTER 11

Parts 1 and II developet a two-pronged contractual anslysis that both justifes shroholke st monopoly of the franchise outside of bunruptey and, more surptisingly, also explains chapter ths roting framework. The application of this analysis in Part 111 counseled, among other things, that clapter 11 needs both morte votes-in that preconfirmation sales of substantial assets should be submitted to a vote, rather than left to the bankruptey court's discretion-and, with respect to directorial elections and class approvals, a different vote. In each context, the analysis concluded that the firm's unsecured creditots should be the voters.

In this Part, 1 address what appears at first to be a major practical problem with the conclusions of Part III: although unsecured creditors might, in the abstract, be the firm's best decisionmakers in chapter 11, the real unsecured creditors of real publicly heid chapter 11 debtors are numerous and highly dispersed. Unsecured creditors therefore are likely to face the same obstacles to effective votingrational apathy and the incentive for individual creditors to free ride-that undermine shareholder voting outside of bankruptcy. ${ }^{224}$ if this is true, amending the Bankruptcy Code to give them the franchise in these contexts would be pointless.

I argue in this Part that the game is in fact worth the candle. After a brief theoretical overview of the logic of collective action, $t$ examine the problems that each of the firm's major constituencies-senior creditors, unsecured creditors, and shareholders-would face were it not represented by a chapter 11 committee. 1 show subsequently how chapter 11 committes help the parties to surmount their collective action probiems, but I aiso note the limitations of the committee solu-

224 See supra Part 1.C. Collective action problens arise whenever a group comprising more than one member would benefit from provision of a collective good. Hardin distinguishes collective goods from "aul Samuelson's "puolic goods," which are characterized not only by impossibulity of exclusion, but also by jointness of supply - that is, consumption of the good by one individual does not diminish the amount of the good available to others. Fardin, suprat note 8, at 17-15; see Pati A. Samatson, The Pure Theory of Public Expenditure, 36 Rev. Econ. \& Stat. 387, 387 (1954), reprinted in Kenneth J. Arrow \& Tibor Scifovsky, Readings in Welfare Economics 179, 179 (1969). The reason for the distinction is the dearth of real-world examples of true pubitic goods. 
ton. Finally, i conclude that unsecured creditors should, as f origlnally argued, be given voting authority. ${ }^{225}$

\section{A. The Theory of Collective Action: A Briet Ovemies}

Recall from the discussion in Part I the irony of this familiar dilemma: if each of the members of a group acts rationally, iational apathy and freenider problems are likely to prevent the group from supplying a collective good despite the fact that it is in the members" collective best interests to do so, ${ }^{226}$ For a deeper understanding of collective action, it is useful to consider Mancur Olson's simplest general statement of the dilemma. Olson defined the net benefit (Ai) to an individual $i$ from $i$ 's contribution to the provision of a collective good in terms of the following equation: $\mathrm{A} i=\mathrm{V} i-\mathrm{C}$, where $\mathrm{V} i$ is the gross benefit to $i$ of the collective good, and $\mathrm{C}$ represents the cost. ${ }^{227}$ Olson argued that unless $\mathrm{A} i>0$ for at least one member of the group, the group is unlikely to succeed absent coercion or other selective incentives. ${ }^{228}$ Defining groups with respect to which no individ-

225 My concern throughout this Part is with intra-class collective action problems. I do not consider the interactions among the classes in chapter 11, except to the extent that these interactions bear on the issue of decisionmaking within classes.

In brief, anecdotal evidence suggests that the constituencies of a chapter it debtor form unstable and largely unenforcable coalitions with one another during the course of a bankruptey case. Senior creditors may ally initially with shareholders, for instance, and subsequently with unsecured creditors. Because these coalitions are unenforceable, they may give rise to prisoner's dilemma problems comparable to those encountered in the context of corporate decisionmaking in takeover negotiations outside of bankruptcy. Coffee, supra note 34, at 1533-44. Interestingly, the fact that many of the attorneys and some of the parties are likely to be repeat players suggests that the game arguably is, or could be, an iterated one, which could enhanee the prospects for cooperation between members of any given coalition and thas strengthen the coalition. See Robert Axelrod, The Evolution of Cooperation 20-21, $124-41(1934)$

226 See supra notes $40-42$ and accompanying text.

227 Oison, supra note 8, at 23; Hardin, supra note 8, at 20. Although Olson was not the first to point out that rational members of a group may have an incentive not to contribute to the provision of a collective good, he did generalize his analysis, whereas previous observers had expressed the logic of collective action only through specific examples. E.g., Hardin. supr: note 8 , at $2 !-22$.

228 Olson supra note 8, at 23-24. Edward Rock has recently pointed out one qualification to Olson's analysis: the important question, in actuality, is whether Ai exceeds the gains available to an individual from alternative courses of action, rather than whether $A i>0$. Thus, if the benefit io an individual from exiting, as when a shareholder sells her stock or a creditor her claim, exceeds the gain she would receive were she to help provide the collective good, then the individual, assuming she is rational, wilf exercise her exit option even if $\mathrm{A} i>0$. Similarly, the individual has an incentive to contribute, even where $A i<0$, if her net benefit 
ual meets this requirement as "Tatent," and groups with at least one $i$ for whom $A i>0$ as "privileged," Olson concluded that the latter groups, but not the forner, are likely to succeed. ${ }^{229}$

Pinthermore, Olson argued that, whereas small groups sometimes are piraleged, large groups are almost athays latent; accordingly, he indiceted that latency is directly related to size. ${ }^{230}$ Hardin disagrees. He argues that the degree of latency is related not to the number of individuals in a group, but instead to the size of its smallest efficacious subgroup, $(\mathrm{k})$, which he defines 10 be the size of the smaliest subgroup whose collective beneft exceeds the cost of providing a collective good to the entire group. ${ }^{23 i}$

Two factors are significant to the determination of $(k)$ for a particular group. First, the greater the benefits of collective action as compared with its costs, the smaller $(\mathrm{k})$ will be. ${ }^{232}$ Second, $(\mathrm{k})$ is inversely proportional to the asymmetry of the group - that is, the smallest effi-

from contribution would exceed the beneit from any of her other alternatives. See Rock, supra note 49, at 455-56. See generally Albert O. Hirschman, Exit, Voice, and Loyalty: Responses to Decline in Firms, Organizations, and States (1970) (examining in a variety of contexts the circuinstances in which the exit option will prevail over the voice option).

229 Olson, supia note 8 , at 49-50. Olson describes groups that fall just short of privileged status as "intermediate" groups. Id. at 50. For purposes of clarity, subsequent discussion refers only to "latent" and "privileged" groups. Rather than speaking of intermediate groups, I characterize latent groups as "mildly latent" or "highly latent" where such qualification is appropriate.

230 Id. at $50-51$.

231 Hardin, supra note 8 , at 46 . Thus, for example, a 100 -member group may be more latent than a 1000 -member group if the smallest group that woutd benefit were they to organize and provide the good themselves were 100 for the 100 -member group, but only 50 for the 1000 member group. A 100-member group might have a (k) of 100 if the collective good in question were a step good-that is, none of the collective good would be provided until a threshold level of contribution had been achieved - and provision of the good were also step, in the sense that each individual's only choice would be to contribute or not to contribute, as opposed to the enoice of whether to contribute coupled with a decision as to how much. See, e.g., id. at 51. An example borrowed from Hardin is illustrative. The collective good of Saturday morning quiet in the suburbs would not be provided in a neighborhood with 100 residents if even one of those residents decided to now her lawn. Id.

For an example of a 1000 member group whose $(k)$ is 50 , assume that 50 stockholders of a corporation own a total of $51 \%$ of its stock- 49 stockholders own $1 \%$ each, perhaps, and i owns $2 \%$-and the remaining 950 stockholders own the remaining $49 \%$, each owning less than $1 \%$. If approving a proposed merger were a collective good-the merger would increase the value of the firm's stock-and approval required a $51 \%$ vote, then $(\mathrm{k})$ would be 50 . That is, 50 would be the smallest number of shareholders who, by casting affirmative votes, could ensure that the merger would be approved.

202 1d. at $40-81$. 
cacious subgroup is smaller if the menbers of a group expect different benefits from provision of a collective good than it is if group nembers have identical interests. ${ }^{233}$ These factors play ani important role tin the analysis of the following Section.

\section{Collective Action Problems in the Absence of Committecs}

The parties collective action in chapter 11-which 1 referred to previously as "providing the collecrive good"-comprises a variety of related activities. Effective oversight of the firm's operations during chapter 11 is part of the collective good, as is negotiating on behalf of one's class, filing motions and other pleadings if necessary, and voting in an informed fashion on a proposed reorganization plan. Together, these activities can be described as "monitoring-and-contesting" the chapter 11 case. . $^{234}$ The purpose of this Section is to consider how likely the parties would be to monitor-and-contest actively in the chapter 11 context if they were not represented by committees. I conduct the inquiry by applying the theoretical insights of the previous Section to each of the firm's major constituencies-senior creditors, unsecured creditors, and shareholders.

The senior class of a chapter 11 firm typically consists of the debtor's lenders - frequently one or a small number of banks. Senior creditors, ${ }^{235}$ unlike the firm's unsecured creditors and shareholders, are not widely dispersed. Thus, this group may have sufficient incentive to monitor-and-contest even in the absence of committee repre-

253 Id. at 68 . Hardin suggests that asymmetry exists where different members of a group place different values on an equivalent amount of the eoliective gond. Id. at 67. Thus, an environmentaily conscious citizen might value a clean stretch of beach much more than other citizens would. But in a corporate context, where one shareholder owned more of the target firm's stock than other shareholders and thus received most of the benefit of a takeover premium, Hardin presumably would not find "asymnetry" bectuse every member of the group would place the same value on each share of stock. 1d. at 70-7i. I will use "asymmetry" to refer to each of these situations, because both have the effect of lowering the size of the firm's smallest efficacious subgroup, (k).

234 Commentators have used various terms to describe the collective good that is supplied if shareholders take an active role, through informed voting and other activities, in the governance of a tirm outside of bankruptey. Black. supra note 49, at 522 (ealling it "shareholder voice"); Rock, supra note 49 , at $453-54$ (describing the collective good as "[d]isciplining"). I use the term "monitor-and-contest" to reflect the somewhat different role of the major "piayers" in a chapter 11 case. In particular, I wish to convey a sense of bankruptey as both a participatory and an adversarial process.

235 The firm's senior creditors are often, but not always, secured. I ussume for the purposes of the following analysis that they are in fact sectred. 
sentation, because the proportion of the benelits to each member of monitoring-and-contesting is significant enough to justify incurring the related costs. ${ }^{236}$

Moreover, even if the class is latent (that is, Ai $<0$ for each memhert, the costs of coordination we usually very low, and free ringing is very dinicult in a class of this size. Accordingly, one might expect that its members will overcome their collective action problem. Hardin! notes, for example, that "solidarity, moral suasion, or strategio interaction" favor the efforts of a small group and that the members of such a group can engage in contingent choosing-that is, each member may implicitly agree to monitor-and-contest on behalf of the ciass only if the other members do the same. ${ }^{237}$ The fact that secured creditors often have an incentive to play an active role does not ensure an optimal contribution so long as each member cannot receive the whole benefit of the collective good. ${ }^{238}$ Nonetheless, the secured class of creaitors is the class least likely to be paralyzed by collective action problems in chapter 11 .

Unlike secured creditors, unsecured creditors such as bondholders and trade creditors are likely to be numerous and widely dispersed. ${ }^{239}$ One might therefore expect a high degree of latency with respect to unsecured creditors, comparable in many respects to the status of shareholders outside of bankruptcy, ${ }^{240}$ If true, this observation sug.

$23 t$ Senior creditors are a classic example of what Olson described as a small, and thus potentially privileged, group. Olson, supra note 8 , at $49-53$,

237 Hardin, supra note 8, at 40. We might therefore expect io see secured creditors taking turns attending negotiating meetings with the debtor and other constituencies and sharing the costs of representing the class in court. Because of the number of bankruptey "events," the collective action game appears iterated for these creditors. As noted above, see supra note 225 , in an iterated prisoner's dilemma game, defection may not be the rational strategy for individual players; cooperation is significantly more likely.

218 Olson, supra note 8 , at $34-36$.

239. The drafters of the Bankruptcy Code were aware of this problem. They observed that debtors may have a "natural tendency ... to pacify large crecitors... at the expense of small and scattered public investors," but that public investors, such as shareholders and bondhoiders, should "have legislative assurance that their interests will be protected." $\mathrm{S}$. Rep. No. 989, 95 th Cong., 2 d Sess. 10, reprinted in 1978 U.S.C.C.A.N. 5787, 5796.

$2+0$ Interestingly, the benefit ( $\mathrm{V} i$ ) of monitoring-and-contesting to an individual unsecured ereditor in chapter 11 may be relatively greater than that to a secured creditor. Secured creditors are compensated first and thus receive most of their clains even if the firm performs badly. The fortunes of the firm and the success of negotiations with other constituencies, however, will directly affect the value available for unsecured ereditors, but this tenefit is offiset by exponentially greater costs to widely dispersed unsecured creditors who wish to provide a public good as compared to secured creditors: 
gests that the smallest efincacious subgroup (k) for a group of unsecured creditors usually will be extremeiy large. Yet the smallest efficacious subgroup of unsecured creditors may be significantly smaller than the total number of members in the plase because the numbers of a class of bondholders or trade creditors frequently will hold clums in substantially diferent motnt, making these classes highly asymmetrical in nature. Thus, a frm that engages in defersse contracting may owe some trade creditors-such as an ofice supply store-small amounts (say, \$500), and other trade creditors-a supplier of parts, for instance-much larger sums (say, 40,000 ). Both are unsecured creditors, but the supplier of parts obviously can expect a much greater benefit if the class monitors-and-contests effectively. Concentration of debt in the hands of institutional or other inyestors creates the same kind of asymmetry with respect to a class of bondholders. ${ }^{241}$ In short, unsecured creditors probably would not effectively monitor-and-contest in most chapter 11 cases, but concentration of large claims in the hands of relatively few investors could reduce the degree of latency in many classes. ${ }^{242}$

The benefit ( $\mathrm{V} i$ ) to the shareholders of active monitoring-and-contesting is limited for an insolvent firm. Nevertheless, because the Bankruptcy Code gives shareholders significant leverage even in contexts where strict application of the absolute priority rule would eliminate their interests entirely, the benefits to shareholders of collective action in chapter 11 should be roughly comparable to those anticipated by unsecured creditors. The cost (C) to shareholders of monitoring-and-contesting also is similar to that to unsecured creditors because shareholders are similarly dispersed. As with unsecured creditors, the shareholders are likely to be a highly latent group, although the size of the smallest efficacious subgroup may be reduced

$2+1$ In addition to asymmetry in the size of creditors claims, my principal concern here, there also may be asymmetry in Hardin's sense-nonfungibility of benefits as among the members of the relevant group. Hardin, supra note 8 , ar 70 . In particular, whereas some unsecured creditors, such as employees, may have a vested interest in the long-term viability of the firm, others may simply wish to ensure that the firm will survive long enough to compensate them. See Roe, supra note 18, at 542-44.

$2 \pm 2$ Postpetition trading of claims can create this concentration and give postpetition investors a much greater incentive to monitor-and-contest than the incentives given the individual claimants from whom the investor bought her claims. See, e.g., Fortgang \& Mayer, supra note 99 , at 6-7. In an extreme case, an investor might acquire such a large stake in a class as to convert the class from latent to privileged status. 
by the concentration of share ownership in the hands of institutional and other large investors. ${ }^{243}$

\section{The Impact of Chapter 11 Committess on Callective Action Problems}

Collective action theorists have posited that highly tafon groups, such as the shareholders and unsecured creditors of a publicly held thapter 11 debtor, ${ }^{2+4}$ will succeed in supplying a collective good only through coercion or selective incentives. ${ }^{245}$ Government intervention presents a third option. ${ }^{2+6}$ The government may provide the collective good itself or may compel the members of a group to contribute to the provision of the collective good. Chapter 11 committees are a classic example of the latter approach. ${ }^{247}$ Chapter 11 committees enable the parties to overcome their collective action problems in two

243 Rock, supra note 49, at 459. Moreover, because several of the shareholders' options ouiside of bankruptcy are significantly less attractive in bankruptey, the likelihood that shareholders will have an incentive to contribute to the collective good, even if the net benefit (Ai) for an individual shareholder is negative, is enhanced. See supra note 228, In particular, the value of the firm's stock is likely to have plummeted, thus curtailing the shareholders' exit option. Additionally, shareholders will no longer be able to anticipate the possibility of takeover gains because an investor who wished to purchase control of a bankrupt firm would likely purchase the claims of a more senior class. See Fortgang \& Mayer, supra note 99, at 75 . 76.

24. History provides evidence in support of the intuition that shareholders and unsecured creditors are likely to face severe collective action problems. The widespread belief that senior creditors and the management of financially troubled firms routinely colluded against widely dispersed public bondholders - that is, took advantage of bondholders collective action problems-provided a major impetus for the bankruptcy reforms of 1938 . See, e.g., Roe, supra note 115 , at $251-52$.

245 Hardin describes two of the most prominent selective incentives as "by-product" theory and "political entrepreneurship." By-product theory suggests that groups already organized for some other purpose will sometimes direct a portion of their resources toward provision of a collective good. Hardin, supra note 8, at 31-35. Political entrepreneurship describes the situation is which the desire for private gain, such as prestige or political advancement, motivates an individual to help provide a collective good for a latent group, Id. at 35-37. Rock has suggested that political entrepreneurship may explain recent high-profile activism outside of bankruptcy by the heads of several public pension funds. Rock, supra note 49 , at $479-81$,

246 Hardin, supra note 8, at 52, 84. Government intervention is a form of coereed contribution similar in many respects to participation in a labor union coerced, for exarnple, by union shop rules. See Olson, supra note 8, at 68 .

247 Bardin refers to government intervention of this sort as a "Baumol solution" to the collective action problem. Hardin, supra note 8 , at 52 ; see also Baumol, supra note 8 , at 180 . 96 discussing circumstances under which government activity may assist individuals in atianing their desired ends). 
related ways. First, commitiees centralize all of the functions necessary to effective monitoring-and-contesting by the class or classes of clams in question. Committees have specific authorization to consult with the debtor in possession about the administation of the cass, to inverighte the operations arth fuances of the debtot, to help drutt a plun and condinate their constivencies' votes, to request that a truste be appointed, and to "perform such oiner services as are th the interest of those represented."

Second, the Bankruptcy Cocie provides for the costs of commitees: to be paid as an administrative expense from the bankruptcy estate; 248 these expenses thus have priority over distributions to shareholders and unsecured creditors. ${ }^{250}$ This arrangement spreads the costs of committees across all claimants. Unlike compensation for insurgents in successful proxy fights or attorneys' fees from derivative suit recoveries outside of chapter 11 , compensation of chapter 11 committees does not depend on a showing of success. ${ }^{253}$ As a result, chapter il committees are likely to be more effective than their counterparts outside of bankruptcy at solving collective action problems, perhaps even causing overmonitoring because of the independence of payment and success. ${ }^{252}$

$2+8$ Bankruptcy Code $\$ 1103(\mathrm{c})(5)$. Congress made clear, both in the language of $\$ 1103$ and in the legisiative history, its intent that committees perform an important monitoring rola throughou the case. See Creditors' Comm. v. Parks Jaggers Aerospace Co. (In re Parks Jaggers Aerospace Co.), 129 B.R. 265, 268 (Bankr. M.D. Fla. 1991) (holding that ereditore' committee does not antomatically dissolve after confirmation of a reorganization plan because reasons may exist for the committee to continue to monitor the debtor's actions)

240 Bankruptcy Code $\$ 330$ (a) (authorizing payment of any "professional person" employed by a conmittee pursuant to Bankruptcy Code $\$ 1103$ ); id. $\$ 503(\mathrm{~b})(2)$ (ensuring that the payments wili be treated as an administrative expense).

25i id. § 507(a).

251 Because proxy contest insurgents will be compensated onily if they are successful (and not for effots expended in losing efiorts or in scrutinizing management proposals that fhey decide not to oppose), potential insurgents will provide an inappropriate amount of monitoring. See Clark, supra note 21 , at $781-82$. Similar shortcomings plagne the rules for payment of attorneys' fees in the derivative suit context. See Clark, supra note $16 . \$ 9.5$, at 356-97. The effectiveness of derivative suits is further limited by their post hoo nuture, making them useful only in remedying actual violations, and by the likelihood that plaintitis' attoneys' incentives will be at odds with those of their clients. John C. Cofiee, 3r., The Unfaithfu! Champion: The Plaintiff as Monitor in Shareholder Litigation, 48 Law \& Contemp. Probs, 5 , $32(1985)$.

25: The effectiveness of committees is enhanced by the enormous leveraging efiect of bankraptey on resources directed toward providing the collective good. Because an indiviluat group member need persuade only a bankrupicy judge of the virtue of her position, rather than 
On the other hand, it may seem puzzling that the Bankruptcy Code requires that only unsecured creditors be given a committee in every case. ${ }^{25.3}$ Appointment of committees for other creditors and for shareholders is completely discretionary..$^{234}$ Yet collective action theory explains even these differences. Recall that the firm's secured credi. tors may have suficient ineentives to monitor-and-contest in chapter 11 even without the aid of a committee. Thus, the drafters understandably denied them the right to be represented by a committee in every case. Shareholders, although facing significant obstacles to collective action, arguably have no financial interest in most chapter 1 ! firms because most are by then insolvent. The desire nonetheless to give shareholders substantial leverage in chapter $I 1$ and the recognition that some chapter 11 firms are not insolvent entitle shareholders to committee representation in appropriate cases. ${ }^{255}$

In contrast, the firm's unsecured creditors are a highly latent group; as the residual owners of the firm, they may need, and arguably should have, a committee in every case. Notice that this representation will be especially important if the Bankruptcy Code is amended,

all or a majority of the members of her group, bankruptcy significantly reduces the costs of monitoring-and-contesting a chapter 11 case, as compared to the cost of engaging in similar activities prior to bankruptcy, Cf. Hardin, supra note 8, at 134-35 (noting that environmental activists, in lobbying the government to enact pollution controls, need spend only a fraction of the money that would be necessary to clean up pollution themselves or to pay individuals and firms to stop polluting); John Woestendiek, Southern Californians Cooking Their Last with Charcoal Fluid, Phila. Inquirer, July 4, 1991, at A1 (antipollution measures will present manufacturets with major expenses but cause individuals only minor inconveniences).

253 Despite the fact that the language of Bankruptey Code section 1102(9) appears to mandate appointment of an unsecured ereditors' committee, LoPucki has shown that unsecured creditors' committees are not always appointed, at least in smaller cases. Lynn M. LoPucki, The Debtor in Full Control-Systems Failure Under Chapter 11 of the Bankruptcy Code? (Part II), 57 Am. Bankr. L.J. 247, $249-53$ (1983). Courts do in fact appoint at least ore committee of unsecured oreditors in nearly every case involving a large, publicly traded corporation. Lo Picki \& Whitford, supra note 148, at 114.

254 Id.

255 Shareholders should not be entitled to the increased ieverage afforded by a committee in cases where the firm is deeply insolvent. In such a case, creditors effectively would be subsidizing the representation of a class that has no colorable financia! interest in the firm, for payment of the equity committee's expenses will diminish the recovery available to the creditors. The decided cases generally support this view. E.g., In re Emons Indus., 50 B. R. 692, 694 (Bankr. S.D.N.Y. 1985) ("getierally no equity committee should be appointed when it appears that a debtor is hopelessly insolvent"); see 5 Collier, supre note 59, of 1102.02, at 110222 to -23 ; see also LoPucki \& Whitford, supra note 84, at 159-60 (suggesting that shareholders are more likely to participate in reorganization distributions if they are represented by an equity committee), 
as this Article recommends, to give unsecured creditors voling control over preconfirmation sales of substantial assets and directorial elections.

The analysis thus far depicts chapter 11 committees as a weltcrafted response to the purtes' collective action problems. Conmittees provide an organizatogal structure, together with an uppropriate taxing mechanism, to those classes that most need them. Nevertheless, the committee solution suffers from seyeral signincant shortcomings.

The first stems from agency costs that arise from the committee's acting in essence as an agent for the class. ${ }^{256}$ The key question, then, is how significantly these agency costs impair the effectiveness of committees. Unlike the agency relationship between managers and the frm, where managers own only a small proportion of the firm's stock and thus have questionable decisionmaking incentives, the Bankruptcy Code contemplates that the seven largest members of the relevant group will serve on its committee. ${ }^{257}$ Although the incentives of these seven members will not perfectly mirror those of the group, these representatives are likely to have a major inancial stake in the results of the group's efforts; this should diminish agency costs.

It is far from clear that these seven members will dictate the posture of any given committee, however. The attorneys and other professionals engaged by committees inevitably play a crucial role in the process. If the attorneys conduct negotiations among themselves, rather than in their clients' presence, for instance, they may largely determine the direction of a given case. ${ }^{258}$ Although this agency problem does not destine chapter 11 committees to failure, because attorneys and other professionals still have a strong incentive to satisfy the needs of their committee, ${ }^{259}$ the alignment of interests is likely to be

\footnotetext{
256 See sources cited supra note 14

257 Bankruptcy Code $\$ 1102(b)(1)$ (committees "shall ordinarily consist of the persons. willing to serve, that hold the seven largest claims" or seven largest amounts of equity securities)

258 Lopucki \& Whitford, supra note 84, at 154 ("reorganization plans are not directly negotiated by the parties in interest, bat rather by intermediaries functioning as the parties' representatives").

299 See, e.g., Hardin, supra note 8 , at 107-08. Hardin notes that although one should view with skepticism the motives of an organization's leaders, their self-interest may dovetail for the most part with the goais of the group, in that leaders will retain their status only to the extent they can persuade their constituency of the effectiveness of their leadership. Id. at 108 .
} 
imperfect at best. Lopucki and whit ford point owt, for instance, that attorneys for the various parties may wish to preserve good relations with one another, even at the cost of failing to pursue fully their clients interests, because they expect to see one another again in future chaprer 11 cases. ${ }^{260}$ In this sense they are tits Hordin's political

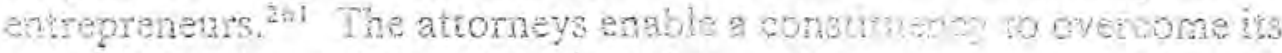
collective action problems, but in doing so they naj pursue a personal agenda that diverges in significant reapeets from the groups' best interests. ${ }^{262}$

A second problem with chapter 11 cormmittees stems from the breadth of their coverage. Consider the unsecured creditors of a publicly held firm. The unsecured creditors of large corporations comprise distinct and potentially conflicting classes ${ }^{263}$ yet the Bankruptcy Code contemplates that a single committee will represent them 211. Bringing diverse classes of unsecured creditors together under a single umbrella may not create difficulties in some contexts, such as monitoring the operations of the firm. In others, however, collective action problems will reemerge: a single committee cannot possibly effectively represent each of three or four different classes with frequently diver. gent interests in the parties' negotiations on division of the reorganization pie. The Bankruptcy Code does specifically authorize the United States trustee (or the bankruptcy court, after notice and a hearing) ${ }^{254}$ to appoint additional committees if she deems them necessary to effective representation. For example, in In re Johns-Hanville Corp, the court appointed several committees of unsecured creditors-including committees for institutional and trade creditors, for asbestos manufacturers, and for asbestos health claimants-in recognition of the

250 Lopucki \& Whitford, supra note 84 , at 156.

26 t Hardin, supra note 8 , at $35-37$.

262 Rock, supra note 49 , at 481 . Rock argues that whereas the heads of publis pension funds similarly may help provide the collective good of shareholder discipline outside of bankruptcy, "their incentives drive them to champion the lands of activities that gamer political benefits but do not benefit the comporation," id.

2b: Typically there are at least three distinct classes of uasecuted creditors of a publicly held firm: senior debenture holders, subordinated debenture holders, and trade creditors. Otten there will be more.

$28+$ Bankruptcy Code \$1102(a)(1). The bankruptcy court originatly appainted commintes. The drafters of the Bankruptcy Code transferred this responsibility to United States trustes to avoid the appearance of favoritism on the part of bankruptcy judges. House Report, supra note 51 , at 101: 5 Collier, supra note 59 , 111102.01 , at 1102-4. 
substantially diferent interests of the various groups. ${ }^{268}$ Tet JohnsManville is exceptional in this respect. Based, presumably, on an implicit conclusion that the advantages of additional commitces are likely to be more than offset by a substantial duplication of costs, the United States trustee (and the court) frequenty appoint mily one cothmitie for unsecured creditors. ${ }^{206}$

A final shortcoming of chapter $1 \mathrm{i}$ committees is their mablity to secure the participation of some or all of a group's seven iargest rambers, either because of time constraints or, more importantly, because of the limitations committee membership may place on their ability to buy and sell claims on the chapter 11 debtor. ${ }^{267}$ Investors who have acquired or augmented their stake in the firm through postipetition trading of claims as well as institutional investors ${ }^{268}$ are especially likely to chafe at the possibility that serving as a committee member will preclude them from trading claims in the future.

\section{Free Agents in Chapter 11: Participation by Individual Claimants and Interest Holders}

From a collective action perspective, then, the chapter 11 committee structure enjoys only mixed success. Providing an organizational structure and a taxing mechanism facilitates monitoring-and-contesting by highly latent groups such as classes of unsecured creditors

265 In re Johns-Manville Corp., 60 B.R. 842, 844-45 (S.D.N.Y.), rev'd on other grounds, 801 F.2d 60 (2d Cir. 1986) (describing the bankruptcy court's appointment oi committees).

206 See LoPucki \& Whitford, supra note 84, at 139. Another possible solution io the problem of diverse strategic interests is for the United States trustee to erisure that each of the divergent classes secures representation on the committee. Thus, the United States trustee might appoint at least one senior unsecured creditor, one trade creditor, and cne subcrdinated unsecured creditor to the committee of unsecured creaitors, regardiess of whether each qualifict as one of the seven largest unsecured claimants. This solution addresses both the problem of duplicative costs and the belief that diverse interests need representation. The committee as a whole still would fail to represent each of the diverse incerests, however. Rather than champion the interests of each of its constituent clisses, the committee would ijkely abstain from negotiations that pitted one unsecured class against another, and instead would limit its efforts to those aspects of the case as to which unsecured ereditors' interests were consistent.

267 Committee members are tikely to receive inside information about the firm. Although the Bankruptcy Code does not explicitly forbid committee members from teading on such information, as Fortgang and Mayer note, "prudent attoneys should advise any client who serves on a committee... that the bankruptcy laws prohibit fiduciaries from trading in the claims or stock of the debtor." Fortgang \& Mayer, supra note 99, at 33.

268 See Rock, supra note 49 , at 494 n.196. 
and harehulders, but agency costs, overly broad coverage, and poss:ble norparticipation suggest that committees ineficiently promote the interssts of their constituencies.

Interestingly, clamants and shareholders with a signifeant stake in a publicly icla debtor sometimes do act on their own initiative, rather than simply relying on a commitree to represent heir interests. Activity of this sort provides empirical evidence (at least of the anecdotal variety) for the contention that committees provide highly imperfect represertation. Yet this activism also raises a question: if the analysis above correctly characterizes shareholders and unsecured creditors as highly latent groups, making collective action illogical in the absence of chapter 11 committees, why do we nevertheless see individuals monitoring-and-contesting? We would expect that regardless of how poorly their committee functioned, individual claimants and interest holders would have insufficient incentives to act alone on behalf of the group. ${ }^{269}$

On closer examination, the apparent incongruity of individual claimant activism is less surprising. Hardin has abserved that groups sometimes overcome their initial latency by "piggybacking"--that is, by borrowing the infrastructures of extant organizations, ${ }^{270}$ He suggests that the use by early environmental groups of existing nature appreciation groups and the use by the Southern civil rights movement of churches are illustrations of this phenomenon. 271 This insight also helos explain the activism of individual claimants and shareholders in chapter 11. These individuals rely on their committee to perform the vast majority of monitoring-and-contesting. They often go so far as to model the pleadings they file (and the positions they take) on motions filed by the committee. One suspects that the level of individual participation would drop dramatically in the absence of this

209 One gossible explanation is that these individuals are motivated by excarational incentives, stich as anger, fear, or ethical concerns. See Hardin, supra note 8, at 10i-24. Examples of such behavior are when the individual investors in a failed real estate venture, or the employes of a loca! business, attend the first meeting of the debtor's creditors, convened under Bankruptcy Code $\$ 341$, for the purpose of venting their emations concening the debtor's finaneiai collapse. In the discussion that follows, I ignore extrarationat considerations because they do not scem to be the principal reason that large investors sometimes participate in the chapler 11 cusc of a publicly held firm.

270 Fiardin borrows the term "piggybacking" from Bernard Grofman. See Hardin, Supra note 8. at 43 a. 11 .

211 Id. at $43-44$, 
commitles antivity, ${ }^{2 / 2}$ In short, piggyoacking appears to piay a crucial role in enatling individual claimants or interest holders to contribute in a mearingful way to the monitoring-and-contesting that tekes plase in chapter 11.

The Batrapter Code argualy encourages such botiviom by providing the mearis to conprd it. Section $503($ b) (3) authorizes a count to reimburse $\& s$ an administrative expense the "actual, necessary expenses" inourred by, among others, creditors and shareholders who "Inake] a substantial contribution" to the case. ${ }^{273}$ Although a bankruptcy court's determinations as to whether and to what extent an individual activist should be compensated for her efforts is subject to many of the same imperfections that undermine the proxy contest and derivative suit tules outside of bankruptcy, ${ }^{274}$ courts could, and should, look to this section as a means of compensating for the limitations of the chapter 11 committee structure. Compensating activism by individual claimants is surely much less expensive than appointing additional committees to ensure that the interests of every class enjoy adequate regresentation.

\section{E. Are Unsecured Creditors Still the Right Voters?}

The suggestion that chapter 11 committees resolve the collective action problems of unsecured creditors and shareholders in oniy an imperfect way retums us to the question with which this Part began: should the Banikruptcy Code be amended to give unsecured creditors voting contro? over preconfirmation sales of substantial assets and directorial elections?

272 Empirical eviderice would be particularly useful here in helping to understand better the mature and extent of individual activism. The analysis in the text stggest that this activism occurs in contey th whe the interests of the various classes represented by a commitee are divergent, or shere the ratio of the benefits to an individual of monitoring-and-contesting to their cost ( $/ / / \mathrm{C})$ is particularly high.

273 In addition, Bankruptcy Code \$ 503(b)(d) authorizes payment of the "actual, necessary expenses" of an attorney or accountant of such creditors and shareholders. Courts in sone cases already compensate individual claimants, interest holders, and their attorneys, pursuant to \&503. Alowough they generally deny compensation for activities that benefit only the individual credior, ses, e.g. In re Johnson, 126 B.R. 808 (Bankr. M.D. Fla. 1991), courts have awarded fees to creditors who objected to a reorganization plan that failed to provide for interesi payments on the claims of unsecured creditors, In re Lehal Realty Assocs. 112 B.R. 588 (Bankr. S.D. N, Y, 1990), or who mediated disputes between the debtor and the creditors. commited. In re Baldwin-United Corp., 79 B.R. 321 (Bankr. S.D. Ohio 1987).

274 See supta note 251. 
Whe respoct to choosing drectors in chapter 11 , the change clearly mould bo an improvernent over the cursent regine. Although committes provide only an imperfect solution to unsecured creditors' collective action problems, shareholders face precisely the same sbatackes. Given unsecured credito s' betrer decisionmaking incerdives, it is more appropriate that they be the yters in the event of an election.

The question of whether unsecured credisors or bankruptcy judges are likaly to make better decisions on preconfimation sales is someWhat closer. Again, however, amending the Bankruptcy Code appears to be the preferable choice. Despite their imperfectly resolved collective action problems, unsecured creditors have much more at stake and can therefore be expected to wield their infuence more effectively.

\section{CONCLUSION}

This Article recommends seyeral changes to the way bankruptcy courts and the Bankruptcy Code currently treat corporate voting in the chapter 11 context. Each proposal is at bottom a suggestion that courts and the Bankruptcy Code should stick more closely to the normative principles reflected in state law corporate voting provisions. Amending the Code to effect these proposals could considerably improve an already well-crafted network of corporate voting rules.

The Article also offers a preliminary inquiry into the nature of the parties' collective action problems in chapter 11. This area seems a particularly promising topic for further study. 